\title{
THE LEFT PERIPHERY OF CP PHASES IN JAPANESE*
}

\author{
KEISUKE YOSHIMOTO
}

Kobe City University of Foreign Studies

9-1 Gakuenhigashi-machi

Nishi-ku, Kobe 651-2187

Japan

keisuke.yoshimoto@gmail.com

Abstract: This paper discusses syntactic conditions under which complement clauses con-
stitute a phase in Japanese. Since CPs are assumed to be phasal (Chomsky 2000; 2001), it
is predicted by the Phase Impenetrability Condition that phrasal extraction out of a CP com-
plement must transit through the edge of the complement, i.e., Spec CP. As Spec CP is an
$\bar{A}$-position and movement through an $\bar{A}$-position must create a uniform A-chain, phrasal extrac-
tion out of a phasal complement is expected to create an $\bar{A}$-chain. However, evidence from
Japanese suggests that long distance A-scrambling is permissible out of some complement
clauses that are headed by an overt complementizer (Uchibori 2000). It follows therefore that
the category CP is not sufficient to characterize clausal phases. In search for an alternative
definition of clausal phases, I argue that main clause phenomena such as thematic topics
and exhaustive foci are allowed only in phasal complements in Japanese. Assuming that Top
and Foc are licensed by Force (Haegeman $2006 a$ ), I propose that phasal complements project
up to Force in their clausal left periphery, independently of a complementizer. I further argue
that the correlation between phasehood and the clausal left periphery can be captured if we
assume that uninterpretable topic and focus features must originate on the phase head Force. assume that uninterpretable topic and focus features must originate on the phase head Force.
Keywords: CP phases, embedded topicalization/focalization, left periphery, feature inheritance

* This paper has come out of my poster presentation at Minimalist Approaches to Syntactic Locality held at the Hungarian Academy of Sciences in 2009. I am grateful to the audiences there who gave me constructive feedback. Special thanks go to Andrew Radford and two anonymous reviewers. The research reported in this paper was partially funded by an Overseas Research Student Award Scheme from the British Government and a University of Essex Postgraduate Research Scholarship. 


\section{Introduction}

An important issue in syntactic theory is the cycle on which syntactic objects built up by operations, i.e., Merge and Move, can be assigned meanings and sounds by interfacing components. Previous approaches in generative grammar assumed that semantics (LF) and phonology (PF) access the syntactic objects only once at the end of the derivation. Within the framework of the Minimalist Program (Chomsky 1993, et seq.), however, it is assumed that narrow syntax feeds semantics and phonology many times in the course of the derivation. This view is put forth by Uriagereka (1999), and developed by Chomsky (2000; 2001; 2004; 2007; 2008 ) in terms of phases. Once the syntactic computation reaches a domain called a phase, elements included within it (except a head and a specifier) are cyclically passed on to LF and PF for evaluation and interpretation. This way, it is possible to minimize the computational load incurred by keeping phrase markers in active memory. Since elements within a phase are taken from narrow syntax, further computation is not able to target anything within the complement of a phase head. This important concomitant of Multiple Spell-Out by phases is known as the Phase Impenetrability Condition.

(1) Phase Impenetrability Condition (PIC)

In phase $\alpha$ with head $\mathrm{H}$, the domain of $\mathrm{H}$ is not accessible to operations outside $\alpha$, only $\mathrm{H}$ and its edge are accessible to such operations. (Chomsky 2000, 108)

Chomsky (2000) argues that phases are propositional domains. Although it is not entirely clear how the semantic notion 'proposition' is encoded in syntax, Chomsky's view is that at least CPs and transitive $v$ Ps are phases. Transitive (but not intransitive) $v$ Ps are considered propositional since they contain a complete argument structure including a thematic external argument, and CPs are propositional in that they include a specification of force. Given this definition of phases, $v$ Ps are split into phasal and non-phasal counterparts depending on the presence of a thematic external argument. Passive and unaccuative $v$ Ps do not count as phases because they do not contain a thematic external argument, and they are called weak phases in Chomsky's terms. On the other hand, it appears that CPs are generally considered phases. This is perhaps because unlike TP complements like raising infinitives, it is often the case that complements headed by an overt complementizer encode (e.g. declarative or interrogative) force. As will be discussed later, however, not all CP com- 
plements headed by an overt complementizer show phasehood properties in Japanese. Nemoto (1993) and Uchibori (2000) argue that long distance A-scrambling is admissible out of control, subjunctive and factive complements in Japanese that are headed by an overt complementizer. This suggests that a subset of complement clauses do not form a phase in spite of their CP status, because if they did form a phase they should block A-movement out of them. The purpose of this paper is to elucidate the syntactic conditions under which complement clauses constitute a CP phase. Since not much research has focused on the defining factor for a domain to constitute a CP phase, it is hoped that this study will contribute to a better understanding of $\mathrm{CP}$ phases from a syntactic perspective.

In particular, by investigating the properties of control, subjunctive and factive complements in Japanese, I will show that the defining property for a domain to constitute a $\mathrm{CP}$ phase is not tense or complementizer choice as Uchibori (2000) proposes, but the entirety of the clausal left peripheral structure. It is argued that Japanese control, subjunctive and factive complements do not permit either the thematic topic $w a$ or the obligatory exhaustive focus ga which are considered to occupy positions in the left periphery of a clause. If control, subjunctive and factive complements do not constitute a phase, this leads to the plausible generalization that a deficient left peripheral structure without TopP and FocP deprives complement clauses of their phasehood. Following Haegeman's (2006a) truncation analysis, I take that the absence of Top and Foc to reflect the absence of Force. So, what Chomsky (2000) means by force can be taken as Force that manifests 'speaker anchoring' in the sense of Haegeman (2006a). ${ }^{1}$ The present paper goes further to analyze the correlation between the phasehood of complement clauses and the totality of their left peripheral structure in terms of feature inheritance (Chomsky 2007; 2008). According to Chomsky (2007; 2008), uninterpretable features originate on a phase head and percolate down to a head immediately below it. If topic and focus features percolate down from a phase head, this

${ }^{1}$ It was brought to my attention by Andrew Radford that there is a similar approach to Dutch clausal phases by Barbiers (2002). While his approach and mine have in common that the presence of ForceP makes a complement clause a phase, we arrive at opposite conclusions. He proposes that factive complements in Dutch constitute a phase because they contain ForceP. On the other hand, I propose that factive complements in Japanese do not form a phase because they do not contain ForceP. 
would seem to mean that Top and Foc are licensed only if there is the phase head Force that can have the relevant features.

This paper is structured as follows. In the following section, I begin by illustrating how phrasal extraction through A-movement is banned by the PIC and Improper Movement. Then, I demonstrate that Japanese control, subjunctive and factive complements are non-phasal as they permit long distance A-scrambling out of them. Section $\mathbf{3}$ argues against Uchibori's (2000) account. In section 4, I present an alternative analysis to Uchibori, according to which non-phasal complements have an impoverished left peripheral structure that lack Force, Top and Foc. Section 5 casts doubt on the application of the recent operator movement approach by Haegeman (2007; 2009; 2010a;b) and Haegeman-Ürögdi (2010) to Japanese. In section $\mathbf{6}$, I propose a preliminary hypothesis that the correlation between phasehood and left peripheral structure can be accounted for in terms of feature inheritance. Section $\mathbf{7}$ concludes the paper.

\section{Phrasal extraction out of complement clauses}

In this section, I outline the predictions that the PIC and Improper Movement make for phrasal extraction, and demonstrate that long distance scrambling in Japanese can be a diagnostic for the phasehood of complement clauses.

Let us begin by looking at the derivation of interrogative sentences. It has long been assumed that wh-questions such as (2a) involve a derivational step in which the $w h$-phrase is moved to the left edge of the phasal complement as in (2b) (the copy of the moved wh-phrase is surrounded by the angled brackets).

(2) (a) What do you think that John bought?

(b) $[\mathrm{CP}$ what that $[\mathrm{TP}$ John bought $\langle$ what $\rangle]]$ ?

In recent developments of the Minimalist Program, Chomsky (2007; 2008) proposes that $\overline{\mathrm{A}}$-movement is triggered by checking of an Edge Feature on a phase head. So, in (2b), the wh-phrase is moved to Spec CP in order to check the Edge Feature on the phase head C. In addition, the PIC in (1) predicts that phrasal movement out of a phasal complement must cyclically target the edge of a phase. This is because the Multiple SpellOut model of derivation would transfer the domain (complement) of the phase, which is TP in (2b). Therefore, if the wh-phrase did not move to 
the edge of the phase at the time of Transfer, it would be frozen within the domain of the phase, and could not undergo further movement to the front of the sentence. Accordingly, we are led to consider that phrasal movement out of a phasal complement must move to the edge of the phase, i.e., Spec CP, in order to be visible to the operation in the next higher phase.

Furthermore, movement to Spec CP has an effect on chain formation. Consider the sentence in (3a) from Chomsky (1973) which shows that movement of John out of the CP complement is banned.

(3) (a) *John seems (that) is intelligent.

(b) [TP John seems [CP $\langle J o h n\rangle[\mathrm{TP}\langle J o h n\rangle$ is intelligent]]].

$\mathrm{A} \quad \overline{\mathrm{A}} \quad \mathrm{A}$

As shown in (3b), John originates in an A-position, and then moves to Spec CP, which is an $\bar{A}$-position. Subsequently, John moves to become the subject of seems, which is an A-position, leading to ungrammaticality. According to Chomsky, movement through mixed A- $\bar{A}-\mathrm{A}$ positions is banned as Improper Movement. Radford (2009) articulates this in line with phase theory as follows.

(4) Mixed Chain Constraint (Radford 2009, 392)

Movement cannot give rise to a mixed chain containing one copy of a constituent which has moved to the edge of a phase, and another which has moved to the edge of a non-phasal projection.

According to the Mixed Chain Constraint, (3a) is ruled out since one of the copies of John moves to the edge of the CP phase, and the other to the edge of the non-phasal TP projection. As we have just seen, phrasal extraction out of a phasal complement must target the edge of a phase, i.e., embedded Spec CP, due to the checking of the Edge Feature on C and the PIC. Consequently, the Mixed Chain Constraint leads us to think that phrasal movement out of a phasal complement must terminate in the edge of a phase, which in the case of a main clause must be Spec CP. Since Spec CP is an $\bar{A}$-position, this is tantamount to stating that (5) generally holds.

(5) Phrasal extraction out of a phasal complement must terminate in an $\bar{A}$-position.

It is interesting to view long distance scrambling in Japanese from the perspective of (5) because many have argued (e.g., Saito 1992; Tada 1993) 
that there are asymmetries between clause-internal and long distance scrambling (see also Mahajan 1990 for a similar observation regarding scrambling in Hindi). Let us first observe clause-internal scrambling. In (6), the pronoun soko 'it' contained in the subject cannot be bound by the quantifier phrase (henceforth QP) mittu izyoo-no daigaku 'three or more universities' in the object position, as the pronoun is not c-commanded by the QP. ${ }^{2}$

(6) ${ }^{*} \mathrm{Soko}_{i}$-no sotugyoosei-ga mittu-izyoo-no daigaku ${ }_{i}$-ni syutugansi-ta.

it-gen graduate-nom three-or.more-gen university-gen apply-past

'Their ${ }_{i}$ graduates applied to three or more universities $i ._{i} \quad$ (Takano 2010, 84)

That is, (6) does not have a bound variable interpretation such that 'there are three or more $x, x$ a university to which someone who graduated from $x$ applied'. When the QP mittu-izyoo-no daigaku 'three or more universities' is scrambled to the sentence initial position where it can c-command the pronoun, this reading becomes available. In this light, let us look at (7).

(7) Mittu-izyoo-no daigaku $_{i}$-ni soko $_{i}$-no sotugyoosei-ga $t_{i}$ syutugansi-ta. three-or.more-gen university-gen it-gen graduate-nom apply-past

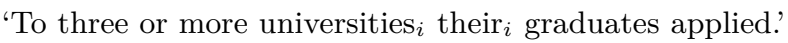

The fact that the QF can bind the pronoun in (7) can be straightforwardly accounted for if we assume that clause-internal scrambling is A-movement. This is because only A-movement can license variable binding as illustrated by contrasts such as those in (8).

(8) (a) $* \mathrm{Who}_{i}$ did his h $_{i}$ mother call $t_{i}$ ?

(b) Every boy $i$ seems to his $i$ mother [ $t$ to be smart].

(Takano 2010, 95)

(8a) is an instance of weak crossover, and his cannot be construed as a variable bound by who from an $\bar{A}$-position. On the other hand, (8b) has an interpretation in which his is a variable bound by every boy; and this is possible because every boy is in an A-position. It is worthy of note that variable binding in (7) also tells us that any movement through the edge of a $v \mathrm{P}$ phase is not relevant to the generalization in (5) in Japanese. If scrambling must target the edge of each phase as suggested by Hiraiwa

2 Some have used binding of the reciprocal anaphor otagai 'each other'. However, since Yatsushiro (2003) argues that reciprocal binding in Japanese is controversial as a judgment test, I stick to variable binding by a quantifier phrase. 
(2010a), scrambling in (7) must transit through the edge of the transitive $v \mathrm{P}$ phase in the course of moving to the front of the sentence. Were this to be the case, it is predicted by the Mixed Chain Constraint that scrambling of the QP terminates in Spec CP, which being in an $\bar{A}$-position, cannot establish a variable binding relation with the pronoun. The fact that this prediction is not borne out in (7) shows that the edge of a $v \mathrm{P}$ phase does not interfere with the formation of an A-chain for some reason. ${ }^{3}$ In the remainder of this paper, therefore, I will not consider the edge of a $v \mathrm{P}$ phase on the assumption that the edge of a $v \mathrm{P}$ phase is not subject to the Mixed Chain Constraint in Japanese.

In contrast to clause-internal scrambling in (7), long distance scrambling out of complements to bridge verbs, i.e., verbs of reporting, cognition and perception, shows a different behavior with respect to variable binding. Observe that the QP mittu-izyoo-no daigaku 'three or more universities' is moved from its original embedded object position in (9a) to the sentence initial position in $(9 \mathrm{~b})$ from where it can c-command the pronoun soko 'it' contained in the matrix subject.

(9) (a) ${ }^{*}$ Soko $_{i}$-no sotugyoosei-ga[Ken-ga mittu-izyoo-no

it-gen graduate-nom Ken-nom three-or.more-gen

daigaku $_{i}$-ni syutugansi-ta to] it-ta/omot-ta/kii-ta.

university-dat apply-past $\quad \mathrm{C}$ say-past/think-past/hear-past

' Their $_{i}$ graduates said/thought/heard that Ken had applied to three or more universities $i$ '

(b) $*$ Mittu-izyoo-no daigaku ${ }_{i}$-ni $\quad$ soko $_{i}$-no sotugyoosei-ga

three-or.more-gen university-dat it-gen graduate-nom

[Ken-ga $t_{i}$ syutugansi-ta to] it-ta/omot-ta/kii-ta.

Ken-nom apply-past C say-past/think-past/hear-past

'To three or more universities their $_{i}$ graduates said/thought/heard that Ken had applied.'

The unavailability of the intended bound variable reading in (9b) suggests that the landing site of long distance scrambling out of these complements is an $\bar{A}$-position from which the scrambled QP cannot create a binding relation. Hence, this is a typical weak crossover configuration like (8a).

${ }^{3}$ Two possible reasons come to mind. One is that the specifier position of transitive $v$ Ps is unspecified for A- and $\overline{\mathrm{A}}$-movement. The other is that scrambling does not have to transit through the edge of a $v \mathrm{P}$ phase. I will leave this issue for future study as it is beyond the scope of this paper. 
Given the generalization in (5), this suggests that the complements to bridge verbs in (9) constitute a phase.

Interestingly, not all long distance scrambling shows the same pattern as (9b). Building on observations about Hindi (Mahajan 1990), Nemoto (1993) argues that long distance scrambling out of obligatory control complements shows the same variable binding effects as clauseinternal scrambling. In this connection, let us observe subject control in (10) and object control complements in (11) headed by the complementizers yoo(ni) or koto. ${ }^{4}$

${ }^{4}$ As far as object control is concerned, Takano (2010) proposes that there is a contrast between cases in which the pronoun is contained in the controller as in (11) and cases in which the pronoun is not contained in the controller as below.

(i) (a) * ${ }^{*} \mathrm{Soko}_{i}$-no sotugyoosei-ga $\mathrm{Ken}_{j}$-ni $\left[\mathrm{PRO}_{j /{ }^{*}}\right.$ mittu-izyoo-no it-gen graduate-nom Ken-dat PRO three-or.more-gen daigaku $_{i}$-ni syutugansu-ru yoo(ni)/koto-o] susume-ta. university-dat apply-pres $\quad \mathrm{C} / \mathrm{C}$-acc recommend-past

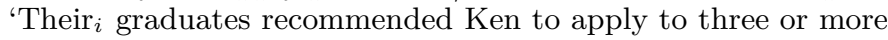
universities $i$ ?

(b) ${ }^{? *}$ Mittu-izyoo-no daigaku ${ }_{i}$-ni $\quad$ soko $_{i}$-no sotugyoosei-ga $\mathrm{Ken}_{j}$-ni three-or.more-gen university-dat it-gen graduate-nom Ken-dat $\left[\mathrm{PRO}_{j / *_{k}} t_{i}\right.$ syutugansu-ru yoo(ni)/koto-o] susume-ta.

PRO apply-pres $\mathrm{C} / \mathrm{C}$-acc recommend-past 'To three or more universities $i$ their $i$ graduates recommended Ken to apply.'

Employing the movement theory of control (e.g., Hornstein 1999), Takano ascribes this difference to the assumption that the variable binding relation is established between the QP and the controller within the complement clause. Therefore, if the pronoun is not contained in the controller, it cannot be bound by the QP in the complement clause, leading to the ungrammaticality of (ib) (cf. (11b)).

Here, I do not follow his assumption that variable binding is established within the complement clause because the movement theory of control is problematic. If $\mathrm{PRO}$ and traces/copies are treated in the same way as suggested by the movement theory of control, it is predicted that they equally obey the Proper Binding Condition (Fiengo 1977). Contrary to this prediction, Hiraiwa (2010b, 141-2) argues from the examples below that only traces/copies are subject to the Proper Binding Condition. In (iia), the remnant including a trace in raising to object constructions is scrambled, and in (iib), the remnant including PRO in object control constructions is scrambled. 
(10) (a) ${ }^{*} \mathrm{Soko}_{i}$-no sotugyoosei ${ }_{j}$-ga $\left[\mathrm{PRO}_{j /{ }^{*} k}\right.$ mittu-izyoo-no daigaku ${ }_{i}$-ni it-gen graduate-nom PRO three-or.more-gen university-dat syutugansu-ru yoo(ni)/koto-o] keikakusi-ta.

apply-pres $\mathrm{C} / \mathrm{C}$-acc plan-past

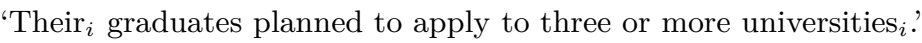

(b) Mittu-izyoo-no daigaku ${ }_{i}$-ni soko $_{i}$-no sotugyoosei $_{j}$-ga three-or.more-gen university-dat it-gen graduate-nom $\left[\mathrm{PRO}_{j /{ }_{k}} t_{i}\right.$ syutugansu-ru yoo(ni)/koto-o] keikakusi-ta. PRO apply-pres $\mathrm{C} / \mathrm{C}$-acc plan-past

'To three or more universities their $_{i}$ graduates planned to apply.'

(11) (a) *Ken-ga soko $_{i}$-no sotugyoosei ${ }_{j}$-ni $\left[\mathrm{PRO}_{j / *}{ }^{*}\right.$ mittu-izyoo-no Ken-nom it-gen graduate-dat PRO three-or.more-gen daigaku $_{i}$-ni syutugansu-ru yoo(ni)/koto-o] susume-ta. university-dat apply-pres $\quad \mathrm{C} / \mathrm{C}$-acc recommend-past

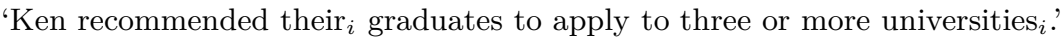

(b) 'Mittu-izyoo-no daigaku ${ }_{i}$-ni Ken-ga soko $_{i}$-no sotugyoosei $_{j}$-ni three-or.more-gen university-dat Ken-nom it-gen graduate-dat $\left[\mathrm{PRO}_{j /{ }^{*} k} t_{i}\right.$ syutugansu-ru yoo(ni)/koto-o] susume-ta.
PRO
apply-pres
$\mathrm{C} / \mathrm{C}-\mathrm{acc}$
recommend-past

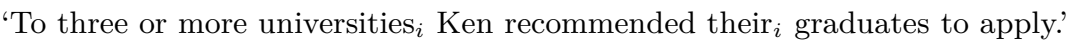
(based on Takano 2010, 86-7)

The sentences in (10) and (11) show that the QP mittu-izyoo-no daigaku 'three or more universities' is scrambled from the embedded object position to the sentence initial position. What is surprising is that the pronoun soko 'it' in the matrix clause can be interpreted as a variable bound by the scrambled QP, which indicates that the QP is in an A-position. If

(ii) (a) $*\left[{ }_{\mathrm{CP}} t_{i}\right.$ Baka-da to $](-\mathrm{wa})_{j}\left[\mathrm{TP}_{\mathrm{TP}}\right.$ Ken-ga Naomi-o $i$

$$
\text { foolish-be C-top Ken-nom Naomi-acc }
$$

(kokorokara) $t_{j}$ omot-ta]]. really think-past

'Ken really considered Naomi to be a fool.' (Hiraiwa 2010a, (18b))

(b) Ken-ga [vP [ ${ }_{\mathrm{CP}} \mathrm{PRO}_{i}$ Boston-e iku koto $]-\mathrm{o}_{j}$ Naomi-ni ${ }_{i} t_{j}$ meizi-ta $\left.]\right]$. Ken-nom PRO Boston-to go C-acc Naomi-dat order-past 'Ken ordered Naomi to go to Boston.' (ibid., (20b))

This shows that the object control construction does not involve movement because if it did the trace left by movement should obey the Proper Binding Condition. 
control complements are phasal, it is expected that the QP terminates in an $\overline{\mathrm{A}}$-position, according to (5). The fact that it does not meet this expectation indicates that long distance scrambling out of control complements does not transit through embedded Spec CP, and therefore is exempted from the Mixed Chain Constraint. It does not transit through embedded Spec CP because this is not forced by the need to check an Edge Feature on a phase head $\mathrm{C}$ or by the PIC. It follows from these considerations that control complements do not constitute a phase.

Furthermore, Uchibori (2000) proposes that long distance A-scrambling is also admissible out of subjunctive and factive complements. ${ }^{5}$ Let us first look at subjunctive complements headed by the complementizers yoo(ni) or koto. As shown in (12), the QP is scrambled from the embedded object position (12a) to the sentence initial position in (12b), from where it can create a binding relation with the pronoun contained in the matrix subject:

(12) (a) ${ }^{*}$ Soko $_{i}$-no sotugyoosei-ga $\left[\right.$ Ken-ga mittu-izyoo-no daigaku ${ }_{i}$-ni

it-gen graduate-nom Ken-nom three-or.more-gen univeresity-dat

syutugansu-ru yoo(ni)/koto-o] negat-ta

apply-pres $\quad \mathrm{C} / \mathrm{C}$-acc wish-past

'Their ${ }_{i}$ graduates wished that Ken would apply to three or more universities ${ }_{i}$.'

(b) 'Mittu-izyoo-no daigaku ${ }_{i}$-ni soko $_{i}$-no sotugyoosei-ga three-or.more-gen university-dat it-gen graduate-nom

[Ken-ga $t_{i}$ syutugansu-ru yoo(ni)/koto-o] negat-ta.

Ken-nom apply-pres C/C-acc wish-past

'To three or more universities their $_{i}$ graduates wished that Ken would apply.'

Factive complements can be divided into true factive and semi-factive complements (Karttunen 1971). True factive complements to verbs such as wasure-ru 'forget' are headed by the complementizers koto or no, and semi-factive complements to verbs like yorokob-u 'be glad' are headed by the complementizers koto or no, as well as to. ${ }^{6}$ Both of them permit long distance A-scrambling out of them, which is shown by variable binding in (13) and (14):

${ }^{5}$ Uchibori (2000) uses other evidence such as scope interaction in order to illustrate long distance A-movement. For ease of exposition and because of space limitations, I only discuss variable binding by a quantifier phrase.

${ }^{6}$ Uchibori (2000) only discusses factive complements headed by koto. However, the complementizers no and to are also important for reasons that will become clear later.

Acta Linguistica Hungarica 59, 2012 
(13) (a) ${ }^{*}$ Soko $_{i}$-no sotugyoosei-ga [Ken-ga mittu-izyoo-no daigaku $_{i}$-ni it-gen graduate-nom Ken-nom three-or.more-gen university-dat syutugansi-ta koto-o/no-o] wasure-ta. apply-past $\quad \mathrm{C}$-acc/C-acc forget-past 'Their ${ }_{i} \operatorname{graduates}_{\text {forgot that Ken had applied to three or more universities }}$.'

(b) ?Mittu-izyoo-no daigaku ${ }_{i}$-ni soko $_{i}$-no sotugyoosei-ga three-or.more-gen university-dat it-gen graduate-nom [Ken-ga $t_{i}$ syutugansi-ta koto-o/no-o] wasure-ta. Ken-nom apply-past $\mathrm{C}$-acc/no-acc forget-past

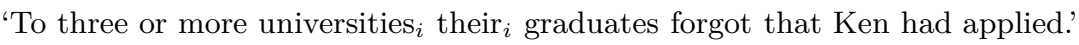

(14) (a) *Soko $i$-no sotugyoosei-ga [Ken-ga mittu-izyoo-no daigaku $i$-ni it-gen graduate-nom Ken-nom three-or.more-gen university-dat gookakusi-ta koto-o/no-o/to] yorokon-da. pass-past $\quad \mathrm{C}-\mathrm{acc} / \mathrm{C}-\mathrm{acc} / \mathrm{C}$ be.glad-past ' Their $_{i}$ graduates were glad that Ken had been accepted by three or more universities $i$.

(b) ${ }^{?}$ Mittu-izyoo-no daigaku ${ }_{i}$-ni soko $_{i}$-no sotugyoosei-ga three-or.more-gen university-dat it-gen graduate-nom [Ken-ga $t_{i}$ gookakusi-ta koto-o/no-o/to] yorokon-da. Ken-nom passs-past $\quad \mathrm{C}-\mathrm{acc} / \mathrm{C}-\mathrm{acc} / \mathrm{C}$ be.glad-past 'By three or more universities $i$ their ${ }_{i}$ graduates were glad that Ken had been accepted.'

Applying the same argument about control complements, we are led to consider that long distance A-movement out of subjunctive and factive complements indicates that they are not phasal either. Since they are not phasal, the QP need not transit through embedded Spec CP. Thus, exempted from the Mixed Chain Constraint, the QP can terminate in an A-position from where it can create a binding relation. ${ }^{7}$

From these considerations of long distance scrambling, one point has become clear. That is, complements to bridge verbs are phasal, while control, subjunctive and factive complements are not in Japanese. Note that we cannot ascribe this distinction to the category of the complements by assuming that non-phasal complements may be TPs. As we have seen, control, subjunctive and factive complements in Japanese are headed by

${ }^{7}$ Basse (2008) argues that phrasal extraction through A-movement is permitted out of factive complements in English as well, and that this reflects non-phasehood of factive complements. 
an overt complementizer, hence they can reasonably be considered CPs. If the $\mathrm{CP}$ status is not sufficient, we are led to ask what precisely defines clausal phases. In the next section, I review an attempt by Uchibori (2000) to answer this question.

\section{The role of tense and complementizers}

In this section, I review a previous study by Uchibori (2000) that aims to account for the non-phasehood of some complement clauses in terms of tense and complementizer choice. For this purpose, before plunging into the details of her analysis, it is necessary to look briefly at the distribution of tense and complementizer selection in Japanese.

Consider first the complementizers we saw in the previous section. The combinations between complementizers and types of complement clause are summarized in (15).

(15) (a) complements to bridge verbs: to

(b) subject control: yoo(ni), koto

(c) object control: yoo(ni), koto

(d) subjunctive: yoo (ni), koto

(e) true factive: koto, no

(f) semi-factive: koto, no, to

Turning now to tense, the tense in complement clauses to bridge verbs can either be past or non-past. As illustrated in (16), the suffix -r(u) marks non-past tense (notated as pres in the glosses) and -ta past tense.

(16) Ken-wa [Naomi-ga sono daigaku-ni syutugansu-ru/syutugansi-ta to]

Ken-top Naomi-nom that university-dat apply-pres/apply-past

C

it-ta/omot-ta/kii-ta.

say-past/think-past/hear-past

'Ken said/thought/heard that Naomi would apply/had applied to that university.'

Insofar as control complements (both subject control and object control) are concerned, the tense in such complements is always non-past as the event described in the complement clause is unrealized at the time of the matrix event. 
(17) (a) $\mathrm{Ken}_{i}$-wa $\left[\mathrm{PRO}_{i / *_{j}}\right.$ sono daigaku-ni syutugansu-ru/*syutugansi-ta Ken-top PRO that university-dat apply-pres/apply-past yoo(ni)/koto-o] keikakusi-ta.

$\mathrm{C} / \mathrm{C}$-acc plan-past 'Ken planned to apply to that university'.

(b) Ken-wa $\mathrm{Naomi}_{i}$-ni $\left[\mathrm{PRO}_{i / *_{j}}\right.$ sono daigaku-ni Ken-top Naomi-dat PRO that university-dat syutugansu-ru/*syutugansi-ta yoo(ni)/koto-o] susume-ta. apply-pres/apply-past $\quad \mathrm{C} / \mathrm{C}$-acc recommend-past 'Ken recommended Naomi to apply to that university.'

We saw in (15) that subjunctive complements as well as control complements are headed by the same complementizers yoo(ni) and koto. Unlike control complements, however, subjunctive complements allow past tense. What is intriguing is that the past tense suffix -ta is only compatible with the complementizer koto. This is made clear by contrasts such as those in $(18 \mathrm{a})$ and $(18 \mathrm{~b})$.

(18) (a) Ken-wa [Naomi-ga sono daigaku-ni gookakusu-ru Ken-top Naomi-nom that university-dat pass-pres yoo(ni)/koto-o] negat-ta.

C/C-acc wish-past

'Ken wished that Naomi would be accepted by that university.'

(b) Ken-wa [Naomi-ga sono daigaku-ni gookakusi-ta

Ken-top Naomi-nom that university-dat pass-past

*yoo(ni)/koto-o] nega-ta.

$\mathrm{C} / \mathrm{C}$-acc wish-past

'Ken wished that Naomi had been accepted by that university.'

True factive complements as well as semi-factive complements permit either past tense or non-past tense as shown in (19).

(19) (a) Ken-wa [Naomi-ga kekkonsu-ru/kekkonsi-ta koto-o/no-o] wasure-ta. Ken-top Naomi-nom marry-pres/marry-past C-acc/C-acc forget-past 'Ken forgot that Naomi was going to get married/had got married.'

(b) Ken-wa [Naomi-ga kekkonsu-ru/kekkonsi-ta koto-o/no-o/to] yorokon-da. Ken-top Naomi-nom marry-pres/marry-past C-acc/C-acc/C be.glad-past 'Ken was glad that Naomi was going to get married/had got married.' 
To recapitulate the observations so far, permissible combinations of complementizers and tense in complement clauses are as follows.
(a) complements to bridge verbs:
(b) subject control:
non-past, past to
(c) object control:
non-past
yoo(ni), koto
(d) subjunctive:
non-past
yoo(ni), koto
(e) subjunctive:
non-past
yoo(ni), koto
(f) true factive:
past koto
(g) semi-factive:
non-past, past koto, no
non-past, past koto, no, to

Tense

Complementizer

Now that we have delineated these properties of complement clauses, we are able to review how the (non-)phasehood of these complements is accounted for in Uchibori's analysis. Central to the issue is non-past tense in (b), (c) and (d) in (20). Since control complements and subjunctive complements headed by yoo(ni) can only have non-past tense, it is plausible to suppose that they are defective in tense. Based on this observation, Uchibori proposes that the defective tense deprives a complement clause of phasal status as in (21).

(21) If a given $\mathrm{C}$ embeds defective/deficient $\mathrm{T}$, the $\mathrm{C}$ does not qualify as a strong phase head.

(Uchibori 2000, 232)

If (21) is on the right track and complements with defective tense do not constitute a phase, it is expected, as seen in the previous section, that long distance A-scrambling will be possible out of control complements and subjunctive complements headed by yoo(ni). However, a natural question that immediately arises from her approach is how we account for the nonphasehood of subjunctives headed by koto (20e) and true and semi-factive complements (20f, g). These complements permit both non-past and past tense forms. Hence, we are not able to resort to defective tense in order to account for the non-phasehood of these complements. Instead of defective tense, Uchibori contends that the nominal nature of the complementizer koto (and no) offers a solution. ${ }^{8}$ Recall that subjunctive complements are headed by koto, and true and semi-factive complements by koto and no. Traditionally, these complementizers are considered nominal in

${ }^{8}$ Uchibori (2000) is only concerned with the complementizer koto, but here I include no because no can also head factive complements and has the same nominal properties as koto. 
nature because they share three properties with relative clauses; that is, (i) obligatory Case-marking on the complementizer, (ii) obligatory adnominal ending on embedded predicates, and (iii) optional nominativegenitive Case conversion on embedded predicates.

Insofar as (i) is concerned, some readers may have noticed from examples like (18) and (19) that the complementizers koto and no are followed the accusative Case marker - - . Since the Case marker is normally attached to a complement noun phrase, this suggests that these complementizers are nominal in nature.

Furthermore, the adnominal ending on predicates further supports the nominal nature of koto/no. In Japanese, predicates can have a special inflection known as the adnominal form. ${ }^{9}$ Insofar as verbs and adjectives are concerned, this is not observable since verbal endings and adnominal endings are not distinct in Modern Japanese. However, copulas and nominal adjectives still differentiate these by the ending $d a$ being realized as $n a$. Observe that the adnominal ending is only permitted in relative clauses (22a), and not in main clauses (22b).

(22) (a) Ken-ga suki-na/*da hito Ken-nom like-cop/cop person 'The person who Ken likes.' (b) Ken-wa Naomi-ga suki-*na/da Ken-top Naomi-nom like-cop/cop 'Ken likes Naomi.'

Bearing this in mind, let us observe that the predicates in subjunctive complements headed by koto and true and semi-factive complements headed by koto/no can have the adnominal ending as shown in (23).

(23) (a) $\mathrm{Ken}_{i}$-wa [Naomi-ga zibun $_{i}$-o suki-na/*da koto]-o negat-ta.

Ken-top Naomi-nom self-acc like-cop/cop C-acc wish-past

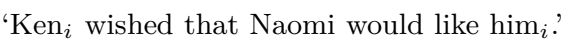

(b) $\mathrm{Ken}_{i}$-wa [Naomi-ga zibun $_{i}$-o suki-na/*da koto-o/no-o] wasure-ta/yorokon-da. Ken-top Naomi-nom self-acc like-cop/cop C-acc/C-acc forget-past/be.glad-past 'Ken forgot/was glad that Naomi liked him $_{i}$ '.

Finally, let us examine nominative-genitive Case conversion on embedded subjects. In Japanese, nominative-genitive Case conversion on subjects between the Case marker - $g a$ and -no is permitted in relative clauses (24a) but not in main clauses (24b) (see Harada 1971; 1976 among others). ${ }^{10}$

9 This is known as rentai kei in traditional Japanese grammar.

${ }^{10}(24 \mathrm{~b})$ is acceptable if no is interpreted as genitive as in '(I) bought Ken's book yesterday' 
(24) (a) Kinoo Ken-ga/no kat-ta hon Yesterday Ken-nom/gen buy-past book 'The book Ken bought yesterday.'

(b) Kinoo Ken-ga/*no hon-o kat-ta. Yesterday Ken-nom/gen book-acc buy-past 'Ken bought the book yesterday.'

With this in mind, it is interesting to see that nominative-genitive Case conversion is permitted on the subject in subjunctive complements headed by koto (25a) and true and semi-factive complements headed by koto/no (25b), which points toward the nominal nature of the complementizers. ${ }^{11}$

(25) (a) Ken-wa [siken-ga/no umaku ik-u koto]-o negat-ta.

Ken-top exam-nom/gen well go-pres C-acc wish-past

'Ken wished that he would pass the exam successfully.'

(adapted from Uchibori 2000, 50)

${ }^{11}$ A reviewer suggested that these complements headed by koto/no could be analyzed as appositive clauses in the sense of Kiparsky-Kiparsky (1970). At first glance, it is tempting to assume so because the complementizers koto/no are considered inherently factive by Kuno (1973), and could be translated into 'the fact that...' in English (but note that koto can also head control and subjunctive complements). Furthermore, the previous literature on nominative-genitive conversion assumes that genitive Case in examples such as in (25) is licensed by an external D-head (Miyagawa 1993; Ura 1993; Watanabe 1994; 1996, but see Hiraiwa 2001 for counterevidence). Notwithstanding these objections, I maintain that these complements headed by koto/no retain their CP status.

In order to show that the three properties discussed above do not necessarily show that koto/no is actually a noun, Uchibori $(2000,51-5)$ adduces the following evidence. First, nominative-genitive conversion is also permitted in subjunctive complements headed by yoo(ni), which in her analysis are CP complements.

(i) Ken-wa [siken-ga/no umaku ik-u yoo(ni)] negat-ta.

Ken-top exam-nom/gen well go-pres $\mathrm{C}$ wish-past

'Ken wished that the exam would go well.'

Secondly, Case particles can also be attached to CPs. This is shown below in which the accusative Case particle $-o$ is attached to an interrogative complement headed by kadooka 'whether'.

(ii) $\mathrm{Ken}_{i}$-wa $\left[\mathrm{PRO}_{i}\right.$ sono siken-o uker-u kadooka]-(o) kime-ta.

Ken-top PRO that exam-acc take-pres whether-acc decide-past

'Ken decided whether to take the exam.'

See also Murasugi (1991) for arguments for the complementizer status of no

Acta Linguistica Hungarica 59, 2012 
(b) Ken-wa [sono tegami-ga/no todoi-ta koto-o/no-o] wasure-ta/yorokon-da. Ken-top that letter-nom/gen arrive-past C-acc/C-acc forget-past/be.glad-past 'Ken forgot/was glad that that letter had arrived.'

Building on these considerations, Uchibori assumes that the speficier of koto is L-related because koto is nominal enough to be regarded as a lexical category. ${ }^{12}$ Let us suppose that the same is true for no because, as has been noted, no has the same nominal properties as koto. For reasons that are not entirely clear, she assumes that if a complementizer is L-related, its specifier becomes an A-position. If this is on the right track, it is possible to account for why long distance A-scrambling is permitted out of subjunctive complements headed by koto (20e) and true and semifactive complements (20f, g), both of which are not defective in tense. If the edge of these complementizers is an A-position, movement through it can constitute an A-chain, and the scrambled QP can create a binding relation as we saw in section $\mathbf{2}$. This is shown in the skeletal form below (the example is a true factive complement headed by koto/no).

(26) (a) 'Mittu-izyoo-no daigaku $_{i}$-ni $\quad$ soko $_{i}$-no sotugyoosei-ga three-or.more-gen university-dat it-gen graduate-nom [Ken-ga $t_{i}$ syutugansi-ta koto-o/no-o] wasure-ta. Ken-nom apply-past C-acc/no-acc forget-past

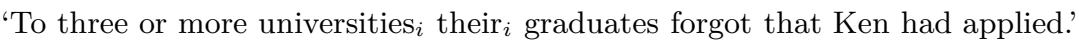

(b) $\left[\mathrm{TP}_{\mathrm{QP}} \mathrm{QP}_{i}\right.$ their $_{i}$ graduates $[\mathrm{CP}\langle\mathrm{QP}\rangle$ koto/no [TP apply $\left.\langle\mathrm{QP}\rangle]\right]$

A
A
$\mathrm{A}$

In other words, her analysis assumes that these complements constitute a phase, yet the special A-status of the edge of L-related complementizers makes phrasal extraction possible through A-movement.

\footnotetext{
based on data from the Toyama Dialect. What is more, if these complements are appositive clauses, they would constitute a strong island. And contrary to the observation in this paper, strong islands would prohibit phrasal extraction through A-movement. Accordingly, one possible way of analyzing this is that koto/no share some nominal properties with nouns, but their category remains CP. As the primary purpose of this section is to review the analysis of Uchibori, it is not necessary to dwell on this matter at this point. See section $\mathbf{5}$ for arguments against treating $\mathrm{CP}$ complements and noun phrases in the same way in terms of referentiality.

12 A position is L-related if it is in a checking configuration with a head containing a lexical feature; otherwise, it is (non)L-related. (Chomsky 1993).
} 
Here, I object to Uchibori's analysis for two reasons. First, contrary to what she claims, koto is not the only complementizer that heads factive complements. As noted in section 2, to can also head semi-factive complements $(20 \mathrm{~g})$, and long distance A-scrambling out of semi-factive complements is admissible irrespective of complementizer choice. The relevant example is repeated here as (27).

\footnotetext{
(a) ${ }^{*} \mathrm{Soko}_{i}$-no sotugyoosei-ga [Ken-ga mittu-izyoo-no daigaku ${ }_{i}$-ni it-gen graduate-nom Ken-nom three-or.more-gen university-dat gookakusi-ta koto-o/no-o/to] yorokon-da. pass-past $\quad \mathrm{C}$-acc/C-acc/C be.glad-past

'Their ${ }_{i}$ graduates were glad that Ken had been accepted by three or more universities ${ }_{i}$.'

(b) ${ }^{?}$ Mittu-izyoo-no daigaku ${ }_{i}$-ni soko $_{i}$-no sotugyoosei-ga three-or.more-gen university-dat it-gen graduate-nom [Ken-ga $t_{i}$ gookakusi-ta koto-o/no-o/to] yorokon-da. Ken-nom pass-past $\quad \mathrm{C}$-acc/C-acc/C be.glad-past 'By three or more universities their $_{i}$ graduates were glad that Ken had been accepted.'
}

Unlike koto and no, the complementizer to does not have three nominal features. That is, semi-factive complements headed by to do not permit nominative-genitive Case conversion on the subject (28a), an adnominal ending on the predicate (28b) and Case-marking on the complementizer (28c).

(28) (a) Ken-wa [siken-ga/*no umaku it-ta to] yorokon-da. Ken-top exam-nom/gen well go-past $\mathrm{C}$ be.glad-past 'Ken was glad that he had passed the exam successfully.'

(b) $\mathrm{Ken}_{i}$-wa [Naomi-ga zibun $_{i}$-o suki-*na/da to] yorokon-da. Ken-top Naomi-nom self-acc like-cop/cop C be.glad-past ' $\mathrm{Ken}_{i}$ was glad that Naomi liked $\operatorname{him}_{i}$.'

(c) Ken-wa [siken-ga umaku it-ta to]-*(o) yorokon-da. Ken-top exam-nom well go-past C-acc be.glad-past 'Ken was glad that he had passed the exam successfully.'

Accordingly, we cannot appeal to the nominal nature of a complementizer to account for the observation that long distance A-scrambling is possible out of semi-factive complements headed by to. Given this and the fact that semi-factive complements are tensed, Uchibori's analysis 
offers no account of why long distance A-scrambling out of semi-factive complements headed by to is possible.

The second reason stems from the fact that the complementizer koto is not exclusive to subjunctive complements (20e) and true and semifactive complements (20f, g). It should be recalled here that the nonphasehood of untensed control and subjunctive complements headed by yoo(ni) is one motivation for her positing a correlation between nonphasehood and defective tense as in (21), which is reproduced here as (29).

(29) If a given $\mathrm{C}$ embeds defective/deficient $\mathrm{T}$, the $\mathrm{C}$ does not qualify as a strong phase head.

To be more specific, the logic behind (29) is that subject control (20b), object control (20c) and subjunctive complements headed by yoo(ni) (20d) are untensed and permit long distance A-scrambling out of them; and since long distance A-scrambling out of a complement implies the nonphasehood of the complement, one possible way of analyzing this would be to consider that untensed complements are non-phasal. We should notice, however, that these complements can be headed by koto. When analyzing tensed subjunctive (20e) and true and semi-factive complements (20f, g), she assumes that long distance A-movement out of these complements is admissible in spite of their tense because movement can transit through the specifier of koto, which has a putative A-status. In other words, this indicates that long distance A-scrambling out of a complement does not entail the non-phasehood of the complement insofar as it is headed by koto, as movement can transit through the specifier of koto anyway. Turning back to control (20b, c) and subjunctive complements (20d), they are untensed, and can be headed by koto. Thus, we face a contradiction in that their defective tense does not guarantee their non-phasehood since phrasal extraction through A-movement is permitted thanks to koto. Accordingly, it seems reasonable to conclude that the logic behind (29) is flawed.

It is apparent that these problems arise from overlaps between analysis by tense and analysis by complementizer choice. Hence, it is desirable not to appeal to either tense or complementizer choice in order to analyze the phasehood of complement clauses. In what follows, I will develop one such analysis that can uniformly account for the (non-)phasehood of complement clauses. 


\section{The left periphery of complement clauses in Japanese}

In this section, I shall propose an alternative analysis to Uchibori which aims to provide a uniform characterization of the (non-)phasehood of complement clauses. Specifically, I will illustrate that non-phasal complements in Japanese do not project TopP and FocP, which are licensed by ForceP in the sense of Haegeman (2006a). This ultimately leads to the conclusion that only complement clauses which have a full left peripheral structure including ForceP can constitute a clausal phase.

Simplifying somewhat, the gist of Haegeman (2003a;b; 2006a;b) is that subordinate clauses come in different sizes in terms of the left peripheral structure; and in particular, Haegeman (2006a) argues that the size of the left periphery is determined depending on whether the proposition is directly related to a speaker, which she dubs as 'speaker anchoring' (see also Bayer 2001; Grewendorf 2002; Benincà-Poletto 2004; Emonds 2004). For instance, Haegeman (2006a) suggests that adverbial clauses can be divided into two types - central adverbial and peripheral adverbial clauses - depending on the degree of the 'speaker anchoring'. While central adverbial clauses merely serve to modify the main clause by giving extra information such as temporal specification, peripheral adverbial clauses have an independent proposition, functioning as the discourse background to the main clause. This point can be made clear by looking at the conjunction while that can have either function. The central adverbial clause in (30a) merely gives temporal specification of the event, whereas the peripheral adverbial clause in (30b) has an independent proposition from the main clause, which reflects the speaker's thought.

(30) (a) These men worked for Clinton while he was governor.

(b) While Dr Williams' support for women priests and gay partnerships might label him as liberal, this would be a misleading way of depicting his uncompromisingly orthodox espousal of Christian belief. (Haegeman 2006a, 29)

The availability of main clause phenomena (henceforth MCP) further highlights the difference between central and peripheral adverbial clauses. Haegeman notes that MCP such as topicalization/focalization are only permitted in peripheral adverbial clauses as shown in (31).

(31) (a) *While this book Mary was writing this time last year, her children were staying with her mother.

(b) His face not many admired, while his character still fewer felt they could praise.

(ibid., 33) 
In a Cartographic approach to the left periphery of clauses initiated by Rizzi (1997), MCP such as topicalization/focalization are considered to involve argument fronting to the positions within CP. The impossibility of these phenomena in central adverbial clauses thus points to a deficiency in their CP-internal structure. Haegeman proposes that the structures for central and peripheral adverbial clauses are as follows.

(32) (a) Central adverbial clause

Sub Fin

(b) Peripheral adverbial clause Sub Top Foc Force Fin

(c) Root clause

Top Foc Force Fin

(Haegeman 2006b, 1663)

Central to this approach is the assumption that the functional projection labeled as Force syntactically encodes the state of affairs that the proposition is directly related/anchored to the speaker. ${ }^{13}$ Since, as noted above, this 'speaker anchoring' is responsible for the availability of embedded topicalization/focalization, it follows that the Force projection licenses Top and Foc. Another important point about the structure in (32) is the separation between Force and Sub, a shorthand for subordinators. Following Bhatt-Yoon 1992, Rizzi (1997, fn.6), Roussou (2000) and others, Haegeman (2006a) proposes that conjunctions situated in Sub in (32) serve to subordinate the clause, and make it available for categorial selection independently of Force. Force limits its function to syntactically encoding speaker anchoring, and licensing of, among other things, illocutionary force and epistemic modality. Therefore, by this separation, we are able to countenance the possibility that subordinating conjunctions may not necessarily encode illocutionary force. While sharing the insight of Haegeman's truncation analysis, I employ the original ordering of CP-layers by Rizzi (1997), as it appears that the location of ForceP below TopP/FocP in (32) is meant just to represent the idea that Force licenses Top and Foc. ${ }^{14}$ Following Radford (2011), the structure of the left periphery of complement clauses is assumed here as follows.

${ }^{13}$ It should be noted that (illocutionary) force is a pragmatic notion and its syntactic counterpart should be clause type (Huddleston 1994). However, I shall set aside this point here since force is a term widely used in the Cartographic literature.

${ }^{14}$ If projections are built up one by one in a bottom up fashion, the ordering of the projections in (32) would make sense to capture the idea that Top and Foc are dependent on the presence of Force in the derivation of a given structure. 
(33) (a) Full clause

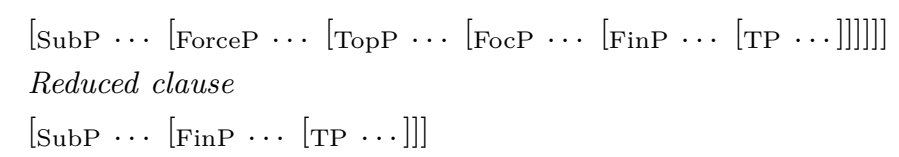

Just like English, control and subjunctive complements in Japanese are not assertive in that the proposition in the complement is unrealized or hypothetical. For a different reason, factive complements in Japanese are not assertive either, as the proposition in the complement is presupposed to be true (Kiparsky-Kiparsky 1970). Assertion reflects the speaker's belief about the proposition, and hence it can be considered commensurate with the 'speaker anchoring' of Haegeman that is encoded in Force. Were this to be the case, it would be expected that in Japanese, complements to bridge verbs should have a full structure like (33a) because they are assertive, whereas control, subjunctive and factive complements should have a reduced structure like (33b) that lacks Force, and concomitantly Top and Foc. Recall, furthermore, that in section $\mathbf{2}$ we argued on the basis of data from long distance scrambling that the former complements are phasal whereas the latter are not. If phasehood and Force are correlated, the following hypothesis can be advanced.

(34) A complement clause constitutes a phase only if it has a full left peripheral structure that projects up to ForceP.

In the following subsections, I shall examine MCP in Japanese, and argue that phasal complement have the full structure in (33a), and non-phasal complements have the reduced structure in $(33 \mathrm{~b})$.

\subsection{Embedded topics in Japanese}

This subsection aims to show that Japanese thematic topics marked by the particle $w a$ are impossible in non-phasal complements, which shows the absence of TopP in their CP-internal structure. Before plunging into the distribution of topics in complement clauses, let us first consider the nature of topicalization in Japanese.

It is well known that in Japanese, topicalized phrases are followed by the particle $w a$, and this $w a$ can be attached to various categories such

However, if projections are built up simultaneously phase by phase, it is not necessary to assume the ordering of the projections in (32).

Acta Linguistica Hungarica 59, 2012 
as NPs (both subjects and objects) and PPs. According to Kuno (1973), topicalized nominal expressions can have two interpretations in sentence initial position: thematic (or aboutness) topic or contrastive topic. ${ }^{15}$ The thematic topic wa serves to introduce the theme of a sentence, and is best translated as 'speaking of ...' 'as for ...'. On the other hand, the contrastive topic $w a$ functions to single out a $w a$-marked entity from other possible entities in the discourse, and generally has stress placed on it. This is shown in (35) (the contrastive topic wa is boldfaced hereafter).

(35) (a) John-wa gakusei desu. John-top student is

'Speaking of John, he is a student.'

(b) John-ga pai-wa tabe-ta ga (keeki-wa tabe-nakat-ta) John-nom pie-top eat-past but (cake-top eat-neg-past)

'John ate (the) pie, but he didn't eat (the) cake.'

(Heycock 2008, 55)

Building on the observation by Saito (1985), Hoji (1985) extensively argues that differences in the interpretation of $w a$ reflect their syntactic positions. The syntactic structures he suggests for wa-objects are schematized as follows.

(36) (a) Sono hon-wa Ken-ga kat-ta.

(thematic topic) that book-top Ken-nom buy-past

'As for that book, Ken bought it.' $\left[\mathrm{S}^{\prime \prime} \mathrm{NP}_{i}\right.$-wa $\left[\mathrm{S}^{\prime}\left[\mathrm{S} \mathrm{NP}\right.\right.$-ga [VP $\left.\left.\left.e c_{i} \mathrm{~V}\right]\right]\right]$

(b) Sono hon-wa Ken-ga kat-ta. (contrastive topic) that book-top Ken-nom buy-past 'Ken bought that book, though probably not other books.' [S $\mathrm{NP}_{i}$-wa [S NP-ga [vP $\left.\left.\left.t_{i} \mathrm{~V}\right]\right]\right]$

The structure in (36a) suggests that the thematic topic is base-generated in some position within $\mathrm{S}^{\prime \prime}$ from where it binds the null pronoun (here notated as ec) within VP. Hoji (1985) notes that $\mathrm{S}^{\prime \prime}$ is not different from Banfield's (1973) E(xpression) projection, which I take to mean a projection within the left periphery here. On the other hand, as shown in the structure in (36b), the contrastive topic originates within VP and is moved/scrambled to adjoin to $\mathrm{S}(=\mathrm{TP})$. The reason for his assuming different syntactic structures for thematic and contrastive topics is

15 A wa-marked NP in non-sentence-initial position is known to have only the contrastive topic interpretation (Kuno 1973). 
that only the contrastive topic shows hallmarks of movement such as reconstruction. ${ }^{16}$

Reconstruction phenomena can be illustrated by examining structures like the following.

$$
\left[e c_{i} / \operatorname{zibun}_{i}\right] \text {-wa } \quad \mathrm{QP}_{i} / \mathrm{NP}_{i} \text {-ga } t_{i} \quad \mathrm{~V}
$$

What (37) shows is that if a topicalized object has been moved over a subject, it should show reconstruction effects. More specifically, it should have interpretations in which the wa-object is a variable/anaphor bound by the subject. As Hoji (1985) illustrates, this reconstruction effect is only observable in contrastive topics. In this light, let us consider the examples below in which (38) illustrates the possibility of a variable bound by a quantifier and (39) binding of the anaphor zibun 'self'.

(38) (a) [NP [ $\left[\begin{array}{llll}\mathrm{S} & e c_{i} & e c_{j} & \text { hitome mi-ta } \\ \text { hito }_{j}\end{array}\right]^{*}$ wa/wa daremo $_{i}$-ga

$e c$ ec one.glance see-past person-top/top everyone-nom

sukininat-ta.

fell.in.love.with-past

A. '*As for the person $_{j}$ that he ${ }_{i}$ saw, everyone $i$ fell in love with $\operatorname{him}_{j}$.'

(thematic topic)

B. 'The person $_{j}$ that he ${ }_{i}$ saw, everyone ${ }_{i}$ fell in love with.' (contrastive topic)

(b) $\left[\mathrm{NP}\left[\mathrm{S} e c_{j} e c_{i} \text { but-ta }\right] \text { hito }\right]_{-}{ }^{*}$ wa/wa dare ${ }_{i}$-ga uttae-ta no.

$e c$ ec hit-past person-top/top who-nom sue-past $\mathrm{Q}$

A. '*As for the person ${ }_{j}$ who hit $\operatorname{him}_{i}$, who $_{i}$ sued him ? $^{\text {? }} \quad$ (thematic topic)

B. 'Lit. The person ${ }_{j}$ who hit $\operatorname{him}_{i}$, who $_{i}$ sued?'? (contrastive topic) $^{2}$

(39) (a) [NP Sono $\operatorname{zibun}_{i}$ nituite-no hon $]_{j^{-}}{ }^{*}$ wa/wa $\mathrm{John}_{i}$-ga sute-ta.

that self about book-top/top John-nom throw.away-past

A. '*As for [the book about himself $]_{j}$, John $_{i}$ threw it ${ }_{j}$ away.'

(thematic topic)

B. '[That book about himself $]_{j}$, John $_{i}$ threw away.' (contrastive topic)

${ }^{16}$ One may wonder if the contrastive topic observes subjacency. Hoji (1985) argues that the contrastive topic that is scrambled out of complex NPs does not have the intended contrastive topic interpretation any more (it has a so-called categorical subject interpretation), which blurs the judgment as to the effect of subjacency. However, as indirect support for the subjacency effect, he suggests that when the contrastive topic is scrambled out of complex NPs, it does not have a variable/anaphor bound interpretation in its reconstructed position. 
(b) $\left[\mathrm{NP}\left[\mathrm{S}\right.\right.$ Mary-ga $e c_{j}$ zibun $_{i}$-ni kure-ta $\left.] \quad \mathrm{hon}_{j}\right]{ }^{*}$ wa/wa $\mathrm{John}_{i}$-ga sute-ta.

Mary-nom ec self-dat give-past] book]-top/top John-nom throw.away-past
A. '*As for [the book that Mary gave to himself $]_{j}$, John $_{i}$ threw it ${ }_{j}$ away.'
(thematic topic)
B. '[The book that Mary gave to himself $\left._{i}\right]_{j}$, John $_{i}$ threw away.'
(contrastive topic)

(Hoji 1985)

Furthermore, Hoji (1985) argues that the structural difference between thematic and contrastive topics can naturally account for distributional differences between them. It is well known that the thematic topic cannot appear in relative clauses as shown in (40).

(40) John-ga [NP [S Mary-*wa/wa $e c_{i}$ non-da $]$ kusuri $\left.{ }_{i}\right]$-o non-da. John-nom Mary-top/top ec drink-past pill-acc drink-past
A. '*John took the pill that as for Mary, she took.'
(thematic topic)
B. 'John took the pill that Mary had taken, though others may not have taken.'
(contrastive topic)
(Hoji 1985)

According to Hoji (1985), this distributional difference immediately follows if $\mathrm{S}^{\prime \prime}$ only occurs in matrix clauses. Since the thematic topic is assumed to be generated within $\mathrm{S}^{\prime \prime}$, it is natural that it cannot occur within relative clauses that do not contain the $\mathrm{S}^{\prime \prime}$ projection. ${ }^{17}$ In contrast, the contrastive topic is allowed in relative clauses if it is generated within VP. If what Hoji calls $\mathrm{S}^{\prime \prime}$ corresponds to TopP in the left peripheral structure, it follows that the distribution of the thematic topic can show the presence/absence of TopP in a given complement clause. ${ }^{18}$

In fact, such an investigation has been conducted by Maki et al. (1999). Their analysis includes the observation that embedded thematic topics are permitted in complements to bridge verbs, but they are not allowed in factive complements headed by no. Applying their observation, Miyagawa (2011) goes further suggesting that thematic topics are not

17 See also Murasugi (1991) and Maki et al. (1999) for arguments that Japanese relative clauses are TP.

${ }^{18}$ See also Kuroda (1988) for discussions that thematic topics are located in Spec CP. 
permitted in non-assertive complements in the sense of Hooper-Thompson (1973), whether they are headed by no or koto (see also Kuroda 2005; Hiraiwa 2010a). ${ }^{19}$

Based on their analyses, let us examine whether a thematic topic is permitted in the different types of complements we looked at in previous sections. First, a thematic topic as well as a contrastive topic is allowed in complements to bridge verbs. This is so whether the subject is topicalized as in (41a) or the object is topicalized as in (41b).

(41) (a) Ken-wa [Naomi-wa/wa kono hon-o yon-da to]

Ken-top Naomi-top/top this book-acc read-past C

it-ta/omot-ta/kii-ta.

say-past/think-past/hear-past

A. 'Ken said/thought/heard that as for Naomi, she had read this book.'

(thematic topic)

B. 'Ken said/thought/heard that Naomi had read this book, though others may not have read it.'

(contrastive topic)

(b) Ken-wa [kono hon-wa/wa Naomi-ga yon-da to]

Ken-top this book-top/top Naomi-nom read-past C

it-ta/omot-ta/kii-ta.

say-past/think-past/hear-past

A. 'Ken said/thought/heard that as for this book, Naomi had read it.'

(thematic topic)

B. 'Ken said/thought/heard that Naomi had read this book, though probably not other books.'

(contrastive topic)

This is straightforwardly accounted for if complements to bridge verbs project up to a TopP that accommodates thematic topics.

Let us now turn to control complements. Since null subjects cannot be topicalized, it is only the embedded object that is at issue here. When the embedded object is topicalized, the intended thematic interpretation is hard to get, yet the contrastive reading is perfectly acceptable as shown below.

${ }^{19}$ Miyagawa (2011) argues that the Japanese politeness marker -mas- only occurs in assertive complements headed by -to (20a) that can be interpreted as direct discourses, and that this politenss marker is licensed in the Speech Act projection (saP) located above CP. Although more research is needed, I assume that what is at issue for phasehood is not saP but rather CP-internal structure for the following reason. Complements to bridge verbs allow the politeness marker -masas in (i) and do not permit long distance A-scrambling out of them as in (9b). 


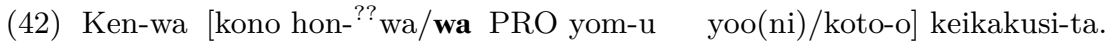
Ken-top this book-top/top PRO read-pres C/C-acc plan-past

A. "? Ken planned that as for this book, he would read it.' (thematic topic)

B. 'Ken planned to read this book, though probably not other books.'

(contrastive topic)

(43) Ken-wa Naomi-ni [kono hon- ${ }^{? ?}$ wa/wa PRO yom-u

Ken-top Naomi-dat this book-top/top PRO read-pres

yoo(ni)/koto-o] motome-ta.

$\mathrm{C} / \mathrm{C}$-acc ask-past

A. "?'Ken asked Naomi to read this book.' (thematic topic)

B. 'John asked Naomi to read this book, though probably not other books.'

(contrastive topic)

A similar asymmetry between thematic and contrastive topics can be found in subjunctive complements. (44a) illustrates a case in which the subject is topicalized and (44b) the object is topicalized.

(44) (a) Ken-wa [Naomi- ?? wa/wa kono hon-o yom-u yoo(ni)/koto-o]

Ken-top Naomi-top/top this book-acc read-pres C/C-acc

negat-ta.

wish-past

A. '?? Ken wished that as for Naomi, she would read this book.'

(thematic topic)

B. 'Ken wished that Naomi, though probably not others, would read this book.'

(i) Ken-wa [Naomi-ga ki-mas-u to] it-ta.

Ken-top Naomi-nom come-politeness-pres C say-past

'Ken said that Naomi would come.'

On the other hand, complements to semi-factive predicates such as yorokob-u 'be glad' (even though they are headed by -to) allow the politeness marker -mas- as in (ii) and do allow long distance A-scrambling out of them as in (14b).

(ii) ? Ken-wa [Naomi-ga ki-mas-u to] yorokon-da.

Ken-top Naomi-nom come-politeness-pres C be.glad-past

'Ken was glad that Naomi would come.'

This implies that saP is not necessarily related to phasehood of a complement clause. 
(b) Ken-wa [kono hon-?? wa/wa Naomi-ga yom-u yoo(ni)/koto-o] Ken-top this book-top/top Naomi-nom read-pres C/C-acc negat-ta. wish-past

A. '?? Ken wished that as for this book, Naomi would read it.'

(thematic topic)

B. 'Ken wished that Naomi would read this book, though probably not other books.'

(contrastive topic)

Thematic topics are not found in true factive complements either. Consider what happens when an embedded subject is topicalized as in (45a) or an embedded object is topicalized as in (45b). ${ }^{20}$

(45) (a) $\operatorname{Ken}_{i}$-wa $\left[\operatorname{zibun}_{i}\right.$-no kodomo- ${ }^{*}$ wa/wa kono hon-o yon-da Ken-top self-gen child-top/top this book-acc read-past no-o/koto-o] kookaisi-ta.

$\mathrm{C}$-acc/C-acc regret-past

A. '?*Ken regretted that as for his child, s/he had read this book.'

(thematic topic)

B. 'Ken regretted that his child, though probably not others, had read this book.'

(contrastive topic)

(b) $\mathrm{Ken}_{i}$-wa [kono hon-?* wa/wa zibun $_{i}$-no kodomo-ga yon-da

Ken-top this book-top/top self-gen child-nom read-past

no-o/koto-o] kookaisi-ta.

$\mathrm{C}$-acc/C-acc regret-past

A. '?*Ken regretted that as for this book, his child had read it.'

(thematic topic)

B. 'Ken regretted that his child had read this book, though probably not other books.'

(contrastive topic)

(Miyagawa 2011, (42))

${ }^{20}$ Maki et al. (1999) is only concerned with factive complements headed by no, but the same is true if they are headed by koto. Although Maki et al. (1999) mark the thematic topic in factive complements as *, it is not entirely ruled out (Hiraiwa 2010; Miyagawa 2011). It should be noted however that the thematic topic in factive complements is worse than that in control, subjunctive complements whose judgment is ??, therefore, I mark it as ?* here. In addition, following Miyagawa (2011), I changed the embedded subject so that the possessor inside it can be coreferential with the matrix subject, which makes the sentence sound more natural when the verb is a true factive like 'regret'.

Acta Linguistica Hungarica 59, 2012 
Thematic topics in semi-factive complements are not as bad as those in true factive complements, yet they are still worse than those in complements to bridge verbs. This is shown in (46).

(46) (a) Ken-wa [Naomi- ?? wa/wa kono hon-o yon-da to] yorokon-da. Ken-top Naomi-top/top this book-acc read-past C be.glad-past

A. '??Ken was glad that as for Naomi, she had read this book.'

(thematic topic)

B. 'Ken was glad that Naomi, though probably not others, had read this book.' (contrastive topic)

(b) Ken-wa [kono hon-?? wa/wa Naomi-ga yon-da to] yorokon-da. Ken-top this book-top/top Naomi-nom read-past $\mathrm{C}$ be.glad-past

A. '?? Ken was glad that as for this book, Naomi had read it.'

(thematic topic)

B. 'Ken was glad that Naomi had read this book, though probably not other books.' (contrastive topic)

From what we have seen in this subsection, it is clear that phasehood and thematic topics are correlated. That is, complements to bridge verbs are phasal, and they permit the thematic interpretation of embedded topics. On the other hand, control, subjunctive and factive complements are non-phasal, and they resist the thematic interpretation of embedded topics. If only thematic topics are accommodated in Spec TopP, one plausible account would be that phasal complements contain TopP whereas non-phasal complements do not. Following Haegeman's assumption that Force licenses Top, this observation points toward the hypothesis in (34) that only full complement clauses that project up to ForceP constitute a clausal phase. In the next subsection, I will investigate whether the same argument can be applied to embedded foci.

\subsection{Embedded foci in Japanese}

The previous subsection argued for a correlation between the phasehood of complements and embedded thematic topics. In this subsection, I aim to argue that the same correlation holds with regard to embedded foci. In this light, I shall investigate the nature of embedded subjects marked by the particle $g a$.

As argued by Kuroda (1965) and Kuno (1973), the interpretation of ga-marked subjects varies depending on the type of predicate. If a 
stage-level predicate is predicated of a $g a$-marked subject, the subject can give rise to either an exhaustive listing focus reading (henceforth exhaustive focus) or a mere neutral description. On the other hand, if a predicate is individual-level, a $g a$-marked subject is forced to have an exhaustive focus reading (here the exhaustive focus $g a$ is boldfaced in example sentences): ${ }^{21}$

(47) (a) John-ga/ga asoko-ni tat-tei-ru.

John-nom/nom there-at stand-prog-pres

A. 'It is John who is standing there.'
B. 'John is standing there.'

(b) John-ga/*ga gakusei desu.

John-nom/nom student is

A. 'It is John who is a student.'

(exhaustive focus)

B. '*John is a student.'

(neutral description)

(Kuno 1973)

Sentences with an exhaustive focus interpretation for $g a$ sound awkward if uttered out of the blue, but they sound natural as an answer to whquestions such as 'Who is standing there?' or 'Who is a student?' Given the difference in interpretations, it is natural to inquire if the interpretations of $g a$-phrases correlate with different structures. However, it is hard to examine structural differences between $g a$-phrases because the $g a$ phrases in question are limited to subjects, and subjects do not scramble. So, unlike the case of $w a$-phrases that can also be objects, it is not possible to detect movement of $g a$-phrases by diagnostics such as reconstruction. ${ }^{22}$

Notwithstanding this problem, the fact that the interpretation of subjects differs depending on predicate type is reminiscent of observations made about indefinite subjects made by Kratzer (1989) and Diesing (1992). Bare plural subjects in English can only have a generic interpretation when a predicate is individual level as in (48), whereas they can have either a generic or existential interpretation when a predicate is stage-level as in (49).

${ }^{21}$ Other than ga-marked subjects, any stressed phrase can receive a focus interpretation in situ in Japanese.

${ }^{22} \mathrm{Ga}$ also marks the object of stative transitive verbs such as in John-wa kuruma-ga suki desu 'John is fond of cars.' But ga-marked objects are irrelevant to the present discussion as they do not have an exhaustive listing focus interpretation.

Acta Linguistica Hungarica 59, 2012 
(48) Ferrets are intelligent.

$G_{x}\left[\right.$ ferrets $\left.^{\prime}(x)\right]$ (intelligent' $\left.(x)\right)$

(49) Ferrets are wet.

(a) $\exists_{x}\left(\operatorname{ferrets}^{\prime}(x) \wedge \operatorname{wet}^{\prime}(x)\right)$

(b) $G_{x}\left[\right.$ ferrets' $\left.^{\prime}(x)\right]\left(\right.$ wet $\left.^{\prime}(x)\right)$

Simplifying somewhat, the gist of their analyses is that existential closure applies to VP, and the different interpretations of bare plural subjects result from their syntactic positions, i.e., above or within VP, when mapping to LF. This is summarized in (50).

(50) Mapping Hypothesis

Material from VP is mapped into nuclear scope.

Material from IP is mapped into a restrictive clause.

(Diesing 1992)

(50) suggests that if a bare plural subject is in IP $(=\mathrm{TP})$ it is interpreted as generic; on the other hand, if it is within $\mathrm{VP}$ (which equates to $v \mathrm{P}$ in the current framework) it is interpreted as existential. Diesing (1992) argues that bare plural subjects of individual-level predicates are basegenerated in Spec TP. Hence, the only option for them is to be mapped into a restrictive clause and have a generic interpretation as in (48). In contrast, bare plural subjects of stage-level predicates originate in Spec $v \mathrm{P}$ and move to Spec $\mathrm{TP}$ in order to be assigned Case. The generic interpretation of a subject would result if it is mapped from Spec TP as in (49b). Alternatively, the subject in Spec TP optionally lowers to Spec $v \mathrm{P}$ at $\mathrm{LF}$, whence it can have an existential interpretation as in (49a).

Applying this, I assume that the interpretation of $g a$-marked subjects in Japanese is affected by their positions when transferred to LF in line with (50). The neutral description reading of subjects can be construed as an existential interpretation as in (51a). The exhaustive focus reading, on the other hand, can be formalized as in (51b) and (52).

(51) John-ga/ga asoko-ni tat-tei-ru.

John-nom/nom there-at stand-prog-pres

(a) 'John is standing there.' (neutral description) $\exists_{x}\left(\mathrm{John}^{\prime}(x) \wedge \operatorname{standing}^{\prime}(x)\right)$

(b) 'It is John who is standing there.' (exhaustive listing) $\exists_{x}\left[\left(\operatorname{John}^{\prime}(x) \& \forall_{y}\left(\operatorname{John}^{\prime}(y) \rightarrow x=y\right)\right) \&\right.$ standing' $\left.^{\prime}(x)\right]$ 
(52) John-ga/*ga gakusei desu.

John-nom/nom student is

'It is John who is a student.' (exhaustive listing)

$\exists_{x}\left[\left(\operatorname{John}^{\prime}(x) \& \forall_{y}\left(\operatorname{John}^{\prime}(y) \rightarrow x=y\right)\right)\right.$ \& student $\left.{ }^{\prime}(x)\right]$

I assume that Japanese $g a$-marked subjects are understood as existential within nuclear scope $v \mathrm{P}$, and as exhaustive focus in the restrictive clause, which I assume to be above $v \mathrm{P}$. Furthermore, I assume that ga-marked subjects of individual-level predicates must be base-generated in Spec FocP, whilst those of stage-level predicates are base-generated in Spec $v \mathrm{P}$, and optionally move out of it. Consider the structure in (53) to illustrate this point (the structure above FocP and below $v \mathrm{P}$ is omitted for ease of exposition).
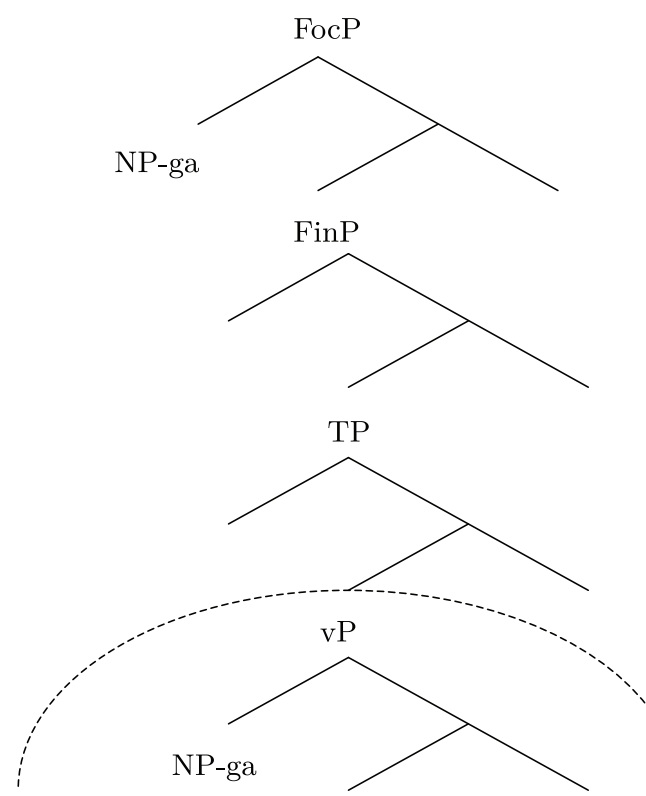

Restrictive clause

Nuclear scope

Heycock $(1994 ; 2008)$ argues that the obligatory exhaustive focus reading of $g a$-subjects is a root phenomenon. Heycock $(2008,58)$ maintains that in unambiguously nonsubordinate clauses, the exhaustive focus reading of $g a$ is forced on the subject of individual-level predicates as in (47b). In contrast, this reading is not forced but merely available in clearly subordinate clauses that preclude MCP. For example, in relative clauses, 
the $g a$-subject need not be interpreted as an exhaustive focus even when the predicate is individual-level:

(54) Taroo-ga [NP [TP Hanako-ga suki-na] hon]-o kat-ta (koto)

Taro-nom Hanako-nom like-cop book-acc buy-past fact

A. '(the fact that) Taro bought a book that Hanako (and only Hanako) likes.'

(exhaustive focus)

B. '(the fact that) Taro bought a book that Hanako likes.' (neutral description)

(Saito 2010, (51))

If Japanese relative clauses are TP (Murasugi 1991; Maki et al. 1999), this may suggest that the obligatory exhaustive focus reading is encoded in the $\mathrm{CP}$ domain. This is in accord with and supports the assumption in (53) that the obligatory exhaustive focus reading would result from $g a$-subjects originating in FocP. The optional exhaustive focus reading in (54) is permitted even without FocP if the $g a$-subject can escape $v \mathrm{P}$, to somewhere like Spec TP, where it can be mapped into the restrictive clause. Hence, by examining whether the $g a$-subject of individual-level predicates is forced to have an exhaustive focus reading, we are able to detect the presence of FocP.

Let us first look at complements to bridge verbs. As shown in (55), an exhaustive focus reading is forced on the embedded subject.

(55) Ken-wa [Naomi-ga/?? ga kasikoi to] it-ta/omot-ta/kii-ta.

Ken-top Naomi-nom/nom smart C say-past/think-past/hear-past

A. 'Ken said/thought/heard that it was Naomi who was smart.'

(exhaustive listing)

B. '??Ken said/thought/heard that Naomi was smart.' (neutral description)

This can be accounted for if the embedded subject in (55) is basegenerated in Spec FocP, whereby it can only have an exhaustive focus interpretation.

Since this diagnostic is only applicable to subjects, we have no definite information on control complements whose subject is null. So let us leave control here and turn to subjunctive complements. As shown in (56), subjunctive complements permit both exhaustive focus and neutral description readings on the embedded subject. 
(56) $\mathrm{Ken}_{i}$-wa [Naomi-ga/ga zibun $_{i}$-ga suki-dea-ru yoo(ni)/koto-o] negat-ta. Ken-top Naomi-nom/nom self-nom fond.of-cop-pres C/C-acc wish-past

A. ' $\mathrm{Ken}_{i}$ wished that it would be Naomi who liked him ${ }_{i}$ ' (exhaustive focus)

B. 'Ken ${ }_{i}$ wished that Naomi would like him $_{i}$. (neutral description)

Similarly, an exhaustive focus reading is not forced on a subject in true factive complements like those in (57), and semi-factive complements like those in (58).

(57) Ken-wa [Naomi-ga/ga kono hon-o yon-da no-o/koto-o] kookaisi-tei-ru. Ken-top Naomi-nom/nom this book-acc read-past C-acc/C-acc regret-prog-pres
A. 'Ken regrets that it was Naomi who read this book.'
(exhaustive focus)

B. 'Ken regrets that Naomi read this book.'

(neutral description)

(58) $\mathrm{Ken}_{i}$-wa [Naomi-ga/ga kono hon-o yon-da to] yorokon-da. Ken-top Naomi-nom/nom this book-acc read-past C be.glad-past

A. 'Ken was glad that it was Naomi who had read this book.' (exhaustive focus)

B. 'Ken was glad that Naomi had read this book.' (neutral description)

Since it is assumed that the lack of the obligatory exhaustive focus interpretation indicates the absence of FocP, this suggests that complements to bridge verbs project FocP, whereas subjunctive and factive complements do not contain FocP. Since the former complements are phasal and the latter are not, this suggests that there is a correlation between phasehood and Foc. Taken together with the observation in the previous subsection, one general point becomes clear: phasal complements have a full structure like (59a) that contains TopP and FocP, and non-phasal complements have a reduced structure like $(59 \mathrm{~b})$ without them.

(59) (a) Phasal CP complements

$[\operatorname{SubP} \ldots[$ ForceP $\cdots[\operatorname{TopP} \cdots[$ FocP $\cdots[$ FinP $\cdots[$ TTP $\cdots]]]]]]$

(b) Non-phasal CP complements

$[\mathrm{SubP} \ldots[\mathrm{FinP} \ldots[\mathrm{TP} \ldots]]]$

Recall that Haegeman's truncation analysis assumes that Top and Foc are licensed by Force. Were this to be the case, the correlation between phasehood and Top/Foc could be replaced by the correlation between phasehood and Force. In other words, this is tantamount to stating that Force is a phase head. Without Force, a complement clause does not 
constitute a phase, and for reasons that will be discussed in section $\mathbf{6}$, such complement clauses are deprived of Top and Foc as well. Consequently, these considerations from Japanese MCP provide strong support for the hypothesis repeated here in (60).

(60) A complement clause constitutes a phase only if it has a full left peripheral structure that projects up to ForceP.

We have seen that complementizer choice in Japanese is not directly relevant to phasehood of complement clauses. It follows therefore that the presence of SubP does not affect phasehood in Japanese. It should also be noted that tense does not affect the internal structure of CPs either. ${ }^{23}$ So, the problems posed by the analysis of Uchibori (2000) in relation to complementizer choice and tense do not arise in the present framework.

\section{Truncation versus operator movement}

The conclusion we arrived at in the previous section is that Force is a phase head, and complements that lack Force are not phasal. Concomitantly, those non-phasal complements lack Top and Foc as well on the assumption by Haegeman (2006a) that Force licenses Top and Foc. As opposed to this truncation analysis, one may wonder if the absence of thematic topics and obligatory exhaustive foci in complement clauses entails the impoverishment of their projections, given the operator movement analysis proposed by Haegeman (2007; 2009; 2010a;b) and HaegemanÜrögdi (2010) (henceforce HÜ). This section aims to provide further evidence in support of the truncation analysis and against the operator movement analysis.

In a series of recent works, Haegeman (2007; 2009; 2010a;b) modifies her own truncation analysis, and suggests that all complement clauses have a full structure like (59a). Instead of clause reduction, she argues that there is movement of an operator to the left periphery as in (61)

${ }^{23}$ A reviewer questions how tense is analyzed in the present analysis if a tense feature is inherited from C. I follow Chomsky $(2007,20)$ in supposing that tense is an inherent property of $\mathrm{T}$, and an interpretable tense feature originates on T. Tense is not directly affected by the internal structure of CP. For example, subjunctive and factive complements have the reduced structure in (59b), but they are tensed. 
that gives rise to an intervention effect with argument fronting such as topicalization and focalization.

(61) $\left[\mathrm{CP} \mathrm{Op}_{i} \mathrm{C}\left[\mathrm{FP} t_{i}[\mathrm{TP} \ldots]\right]\right]$

(Haegeman 2007)

Empirical support for operator movement comes from wh-movement in temporal clauses. In this light, consider (62).

(62) (a) *When this column she started to write last year, I thought she would be fine.

(b) *When this song I heard, I remembered my first love.

(c) When last year she started to write this column, I thought she would be fine. (Haegeman 2010a, 597)

(62) shows that there is an asymmetry between argument fronting $(62 \mathrm{a}, \mathrm{b})$ and adjunct fronting (62c). Based on analyses which assume that temporal adverbial clauses are derived by wh-movement of a temporal operator to the left periphery (Geis 1970; Larson 1987; 1990; Johnson 1988; Demirdache-Uribe-Etxebarria 2004 among others), she concludes that the operator in the left periphery intervenes with argument fronting but it does not do so with adjunct fronting. As shown in (63), this asymmetry between argument fronting and adjunct fronting is independently detected in relative clauses that involve operator movement.

(63) (a) These are the students who in the next semester will study these texts.

(b) *These are the students who these texts will study in the next semester.

(ibid.)

The point of concern is that the same asymmetry is observed in factive complements:

(64) (a) I regret that in those days I didn't realize the importance of classical languages.

(b) *John regrets that this book Mary read. (Maki et al. 1999, (2c))

Based on this observation and others, HÜ conclude that there is also operator movement in factive complements that gives rise to an intervention effect, and that this operator makes factive complements referential in the same way as DPs (see also de Cuba-Ürögdi 2009).

In Japanese, no such asymmetry can be found in environments where operator movement is supposed to be involved. As shown in (65), no 
thematic topicalization of either an argument or an adjunct is allowed in the relative clause.

(65) (a) *Ken-wa [NP [TP sono hon-wa kinoo yon-da] hito]-o home-ta. Ken-top that book-top yesterday read-past person-acc praise-past 'Ken praised the person who as for that book, s/he had read it yesterday.'

(b) *Ken-wa [NP [TP kinoo-wa sono hon-o yon-da] hito]-o home-ta. Ken-top yesterday-top that book-acc read-past person praise-past 'Ken praised the person who as for yesterday, s/he had read that book.'

How, then, do we know whether there is operator movement in Japanese? Note that both the truncation analysis and the operator movement analysis would predict that argument fronting (e.g., thematic topics and obligatory exhaustive foci) is disallowed. So, argument fronting alone cannot be decisive evidence to determine which analysis is more appropriate. Rather, what is crucial is the existence of a weak island as shown in (66).

(66) *Why did you notice that Maria fixed the car $t$ ?

(HÜ, (15b))

The operator movement analysis can account for the weak island in (66) because wh-movement across the operator in the left periphery of the embedded clause contravenes Relativized Minimality (Rizzi 1990; 2004). On the other hand, the truncation analysis I employ here cannot account for (66) because there is nothing to prevent movement of the wh-phrase to the front of the sentence. So, by examining whether a relevant clause constitutes a weak island, we are able to know which analysis is suitable for Japanese.

In fact, Hiraiwa (2010b) argues that factive complements in Japanese are weak islands, and illustrates this claim in terms of the following data:

(67) (a) Ken-ga [Naomi-ga dare-kara-mo okane-o moraw-anakat-ta Ken-nom Naomi-nom who-from-even money-acc receive-neg-past koto-o/no-o] sira-nakat-ta sooda.

C-acc/C-acc know-neg-past hear.say

'I heard that Ken didn't know that Naomi didn't receive money from anyone.'

(b) ?? Dare-kara ${ }_{i}$-mo Ken-ga [Naomi-ga $t_{i}$ okane-o moraw-anaka-ta who-from-even Ken-nom Naomi-nom money-acc receive-neg-past koto-o/no-o] sira-nakat-ta sooda.

C-acc/C-acc know-neg-past hear.say

'I heard that Ken didn't know that Naomi didn't receive money from anyone.'

(Hiraiwa 2010, (12)) 
Furthermore, following Watanabe (1996), Hiraiwa maintains that the adnominal form of predicates arises from operator movement, since the adnominal form typically appears in relative clauses that involve operator movement. Recall that in section $\mathbf{3}$ we saw that complements headed by koto/no require a predicate in an adnominal form, and that (true and semi-)factive clauses are one such complement. The relevant example is repeated in (68).

(68) $\mathrm{Ken}_{i}$-wa [Naomi-ga zibun $_{i}$-o suki-na/*da koto-o/no-o] wasure-ta/yorokon-da. Ken-top Naomi-nom self-acc like-pres/pres C-acc/C-acc forget-past/be.glad-past ' $\mathrm{Ken}_{i}$ forgot/was glad that Naomi liked him $_{i}$.'

Thus, if the adnominal form is a manifestation of operator movement, it follows that factive complements constitute a weak island because of operator movement. However, things do not work the same way for subjunctive complements. As noted in section $\mathbf{2}$, subjunctive complements can also be headed by koto, and so a predicate ends in an adnominal form. The relevant example is (69).

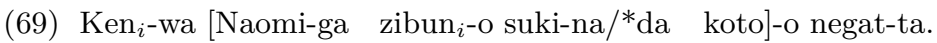

Ken-top Naomi-nom self-acc like-pres/pres C-acc wish-past

' $\mathrm{Ken}_{i}$ wished that Naomi would like $\operatorname{him}_{i}$.'

If the adnominal form results from operator movement, it is predicted that subjunctive complements will also constitute a weak island. However, this prediction is not borne out. As shown in (70), extraction of a whphrase out of a subjunctive complement is not as bad as $(67 \mathrm{~b})$.

(70) (a) Ken-ga [Naomi-ga dare-kare-mo okane-o moraw-ana-i

Ken-top Naomi-nom who-from-even money-acc receive-neg-pres

koto]-o negat-ta sooda.

C-acc wish-past hearsay

'I heard that Ken wished that Naomi would not receive money from anyone.'

(b) ?Dare-kara ${ }_{i}$-mo Ken-ga [Naomi-ga $t_{i}$ okane-o moraw-ana-i

who-from-even Ken-nom Naomi-nom money-acc receive-neg-pres

koto]-o negat-ta sooda.

C-acc wish-past hearsay

'I heard that Ken wished that Naomi would not receive money from anyone.'

Accordingly, this suggests that the adnominal form of predicates does not necessarily entail operator movement. Nonetheless, one could still argue 
that operator movement is involved only in factive complements as they constitute a weak island. However, in the face of the literature arguing that factive islands are a semantic/pragmatic rather than a syntactic phenomenon (Szabolcsi-Zwarts 1993; Oshima 2007 among many others), the motivation for operator movement is weakened. ${ }^{24}$ The bigger problem is that it is unclear why thematic topics and obligatory exhaustive foci are precluded in non-phasal complements other than factives. As just noted, subjunctive complements do not constitute a weak island; and neither do control complements as shown in (71) and (72). ${ }^{25}$

(71) (a) $\mathrm{Ken}_{i}$-ga $\left[\mathrm{PRO}_{i / *_{j}}\right.$ dare-kara-mo okane-o moraw-ana-i

Ken-nom PRO who-from-even money-acc receive-neg-pres

yoo(ni)/koto-o] keikakusi-ta sooda.

$\mathrm{C} / \mathrm{C}$-acc plan-past hearsay

'I heard that Ken planned not to receive money from anyone.'

(b) Dare-kara-mo $\mathrm{Ken}_{i}$-ga $\left[\mathrm{PRO}_{i /{ }^{*} j} t\right.$ okane-o moraw-ana-i

who-from-even Ken-nom PRO money-acc receive-neg-pres

yoo(ni)/koto-o] keikakusi-ta sooda.

$\mathrm{C} / \mathrm{C}$-acc plan-past hearsay

'I heard that Ken planned not to receive money from anyone.'

(72) (a) Ken-ga Naomi ${ }_{i}$-ni $\left[\mathrm{PRO}_{i /{ }^{*} j}\right.$ dare-kara-mo okane-o

Ken-nom Naomi-dat PRO who-from-even money-acc

moraw-ana-i yoo(ni)/koto-o] susume-ta sooda.

receive-neg-pres $\mathrm{C} / \mathrm{C}$-acc recommend-past hearsay

'Ken recommended Mary not to receive money from anyone.'

(b) ?Dare-kara-mo Ken-ga Naomi ${ }_{i}$-ni $\left[\mathrm{PRO}_{i / *_{j}} t\right.$ okane-o

who-from-even Ken-nom Naomi-dat PRO money-acc

moraw-ana-i yoo(ni)/koto-o] susume-ta sooda.

receive-neg-pres $\mathrm{C} / \mathrm{C}$-acc recommend-past hearsay

'Ken recommended Mary not to receive money from anyone.'

If weak islands are a hallmark of operator movement, this suggests that subjunctive and control complements do not involve operator movement. Thus, the operator movement analysis is not able to account for the

${ }^{24}$ See also Basse (2008) for an alternative to the operator movement analysis of factive islands.

${ }^{25}$ It appears that copulas and nominal adjectives that inflect for an adnominal ending cannot readily occur in control complements. 
absence of thematic topics and obligatory exhaustive foci in these complements. ${ }^{26}$ Viewed in this light, it seems reasonable to conclude that thematic topics and obligatory exhaustive foci are disallowed in these complements for reasons other than operator movement.

In contrast, the truncation analysis can account for this by assuming that these complements lack Top and Foc projections. Furthermore, the advantage of the truncation analysis is that it can uniformly account for the link between phasehood and Top/Foc, whilst an operator has nothing to do with phasehood. Accordingly, in the absence of decisive evidence for operator movement in Japanese, I assume that the absence of thematic topics and obligatory exhaustive foci indicates the lack of Top and Foc projections.

\section{Implications for phase theory}

The discussion in this paper makes it clear that complement clauses come in different sizes and that phrasal extraction through A-movement is only permitted out of reduced clauses that lack TopP and FocP. If phrasal extraction through A-movement can detect phasehood, clause size and phasehood are considered to be correlated. Having observed so, this still leaves us the question of why phasehood and topicalization/focalization have to be related in this way. The key to understanding this may lie in the idea that topic and focus are formal features inherited from a phase head in line with the theory of feature inheritance (Chomsky 2007; 2008).

Chomsky claims that non-phasal heads enter the derivation carrying only interpretable features, and that they inherit uninterpretable features from the phase head immediately above them. For instance, agreement features were thought to originate on T, but given evidence such as West Flemish complementizer agreement (Haegeman 1992), they are now considered to enter the derivation on the phase head C. Thus, in order for $\mathrm{T}$ to have agreement with a subject and trigger movement of the subject to its Spec, T must be selected by $\mathrm{C}$ to inherit agreement features.

In relation to this, Radford (2011) discusses the distribution of that in spoken English, and argues that its varied distribution in the left periphery can be ascribed to feature inheritance. He assumes that the function of that in spoken English is to mark finiteness, and that that can lexicalize

${ }^{26}$ Insofar as obligatory exhaustive foci are concerned, we are not sure if control complements resist them. 
any head in the left periphery that inherits finiteness features from the topmost Force. Of particular importance is that the features are inherited from Force because Force is assumed to be a phase head, in accordance with the present paper.

Viewed in this light, it is not unreasonable to suppose that feature inheritance applies to topic and focus features as well. In fact, Miyagawa (2010) argues that topic/focus features originate on the phase head $\mathrm{C}$ and percolate down as far as $\mathrm{T}$. In his theory, topic/focus features in so-called discourse-configurational languages like Japanese function in the same way as agreement features in agreement-based languages such as English. Miyagawa assumes that topic/focus features inherited from $\mathrm{C}$ can attract a goal to Spec TP in Japanese in the same way as agreement features inherited from $\mathrm{C}$ can attract a goal to Spec TP in English. While I assume that topic and focus are uninterpretable features inherited from the phase head, I tentatively propose here that, unlike in Miyagawa (2010), they do not percolate down as far as T. This is because if topicalization/focalization involve movement to Spec TP, we are not able to account for why thematic topics and obligatory exhaustive foci are not permitted in relative clauses that are considered TP (see (40) and (54)). Considering the distributional limitation of thematic topics and obligatory exhaustive foci, it is plausible to think that topicalized/focalized phrases are located in the positions above TP: Spec TopP and Spec FocP, respectively. ${ }^{27}$ More specifically, on the assumption that Force is the phase head, I assume that uninterpretable topic and focus features must originate on Force, and that the projections TopP and FocP are licensed by these uninterpretable features. ${ }^{28}$ This would mean that TopP and FocP must be selected by the phase head because they need uninterpretable topic and focus features that originate on the phase head. Although more research is needed, this line of reasoning by feature inheritance gives us a way of understanding why phasehood and topicalization/focalization are correlated.

${ }^{27}$ More recently, Miyagawa (2011) (unlike Miyagawa 2010) assumes that the thematic topic undergoes movement to the $\mathrm{CP}$ domain.

${ }^{28}$ It might be objected that $\mathrm{T}$ is always present even if it is not selected by $\mathrm{C}$ and has no uninterpretable features. But $\mathrm{T}$ has an interpretable tense feature to license a TP projection, yet Top and Foc do not have such interpretable features. 


\section{Conclusion}

This paper has set out to explore the precise syntactic conditions under which complement clauses constitute a clausal phase in Japanese. Evidence from long distance scrambling shows that not all complements are phasal despite the fact that they are headed by an overt complementizer; and this indicates that it is not sufficient to define clausal phases just by their CP status. Considerations relating to Main Clause Phenomena led me to conclude that the difference between phasal and non-phasal complements can be ascribed to the structure of their clausal periphery. Only non-phasal complements resist thematic topics and obligatory exhaustive foci, and this points to the absence of Top and Foc in their left periphery. It was argued that Top and Foc are licensed by Force which, in Haegeman's (2006a) approach, encodes the speaker's attitude to the proposition. Accordingly, the precise definition is that Force is the phase head, and only complement clauses that project up to ForceP constitute a phase. I also advanced a preliminary hypothesis about the correlation between phasehood and the structure of the clausal left periphery, according to which Top and Foc need to be licensed by uninterpretable topic and focus features that must originate on the phase head Force.

The results reported in this paper have the important implication that information structure may affect cyclic syntactic computation. In other words, the paper has suggested a possibility that constituents in the clausal left periphery affect syntactic locality in terms of Multiple Spell-out by phases, other than that in terms of some form of Relativized Minimality (Starke 2001; Rizzi 2004; Endo 2007). Since the territories of phases and Relativized Minimality do not always overlap especially when phrasal extraction via A-movement is concerned, it should come as no surprise if the definition of syntactic locality presented in this paper is independently necessary.

\section{References}

Banfield, Ann 1973. Narrative style and the grammar of direct and indirect speech. In: Foundations of Language $10: 1-39$.

Barbiers, Sjef 2002. Remnant stranding and the theory of movement. In: Artemis Alexiadou - Elena Anagnostopoulou - Sjef Barbiers - Hans-Martin Gärtner (eds): Dimensions of movement: From features to remnants, 47-67. John Benjamins, Amsterdam \& Philadelphia. 
Basse, Galen 2008. Factive complements as defective phases. In: Natasha Abner-Jason Bishop (eds): Proceedings of the 27th West Coast Conference on Formal Linguistics, 54-62. Cascadilla Proceedings Project, Somerville MA.

Bayer, Josef 2001. Asymmetry in emphatic topicalization. In: Caroline Féry - Wolfgang Stemefeld (eds): Audiatur vox sapientiae: A Festschrift for Arnim von Stechow, 15-47. Akademie Verlag, Berlin.

Belletti, Adrianna (ed.) 2004. Structures and beyond: The cartography of syntactic structures, vol. 3. Oxford University Press, Oxford.

Benincà, Paola - Cecilia Poletto 2004. Topic, focus and V2: Defining the CP sublayers. In: Luigi Rizzi (ed.): The structure of CP and IP: The cartography of syntactic structures, vol. 3, 52-75. Oxford University Press, Oxford.

Bhatt, Rakesh - James Yoon 1992. On the composition of Comp and parameters of V2. In: D?? Bates (ed.): Proceedings of WCCFL X, 41-52. CSLI Publications, Stanford.

Chomsky, Noam 1973. Conditions on transformations. In: Stephen Anderson-Paul Kiparsky (eds): A Festschrift for Morris Halle, 232-86. Holt, Reinhart and Winston, New York.

Chomsky, Noam 1993. A minimalist program for linguistic theory. In: Kenneth HaleSamuel J. Keyser (eds): The view from building 20. Essays in linguistics in honor of Sylvain Bromberger, 1-52. MIT Press, Cambridge MA.

Chomsky, Noam 2000. Minimalist inquiries: The framework. In: Roger Martin-David Michaels - Juan Uriagereka (eds): Step by step: Essays on minimalist syntax in honor of Howard Lasnik, 89-155. MIT Press, Cambridge MA.

Chomsky, Noam 2001. Derivation by phase. In: Michael Kenstowicz (ed.): Ken Hale: A life in language, 1-52. MIT Press, Cambridge MA.

Chomsky, Noam 2004. Beyond explanatory adequacy. In: Belletti (2004, 104-31).

Chomsky, Noam 2007. Approaching UG from below. In: Uli Sauerland-Hans-Martin Gärtner (eds): Interfaces + recursion = language? Chomsky's minimalism and the view from syntax-semantics, 1-29. Mouton de Gruyter, Berlin \& New York.

Chomsky, Noam 2008. On phases. In: Robert Freidin-Carlos P. Otero-Maria Luisa Zubizarreta (eds): Foundational issues in linguistic theory. Essays in honor of Jean-Roger Vergnaud, 134-66. MIT Press, Cambridge MA.

Cuba, Carlos de-Barbara Ürögdi 2009. Eliminating factivity from syntax: Sentential complementation in Hungarian. In: Marcel den Dikken-Robert M. Vago (eds): Approaches to Hungarian 11: Papers from the New York conference, 29-64. John Benjamins, Amsterdam \& Philadelphia.

Demirdache, Hamida - Myriam Uribe-Etxebarria 2004. The syntax of time adverbs. In: Jacqueline Guéron - Jacqueline Lecarme (eds): The syntax of time, 143-80. MIT Press, Cambridge MA.

Diesing, Molly 1992. Indefinites. MIT Press, Cambridge MA

Emonds, Joseph 2004. Unspecified categories as the key to root constructions. In: David Adger-Cécile de Cat-George Tsoulas (eds): Peripheries, 75-120. Kluwer, Dordrecht.

Endo, Yoshio 2007. Locality and information structure: A cartographic approach to Japanese. John Benjamins, Amsterdam \& Philadelphia. 
Fiengo, Robert 1977. On trace theory. In: Linguistic Inquiry 8:35-61.

Geis, Michael 1970. Adverbial subordinate clauses in English. Doctoral dissertation, MIT.

Grewendorf, Günther 2002. Left dislocation as movement. In: Georgetown University Working Papers in Theoretical Linguistics 2:31-81.

Haegeman, Liliane 1992. Theory and description in generative syntax: A case study of West Flemish. Cambridge University Press, Cambridge.

Haegeman, Liliane 2003a. Conditional clauses: External and internal syntax. In: Mind and Language $18: 317-39$.

Haegeman, Liliane 2003b. Notes on long adverbial fronting in English and the left periphery. In: Linguistic Inquiry 34:640-9.

Haegeman, Liliane 2006a. Argument fronting in English, Romance CLLD and the left periphery. In: Raffaella Zanuttini - Héctor Campos - Elena Herburger - Paul Portner (eds): Negation, tense and clausal architecture: Cross-linguistic investigation, 27-52. Georgetown University Press, Washington DC.

Haegeman, Liliane 2006b. Conditionals, factives and the left periphery. In: Lingua 116 : 1651-69.

Haegeman, Liliane 2007. Operator movement and topicalization in adverbial clauses. In: Folia Linguistica $18: 485-502$.

Haegeman, Liliane 2009. The movement analysis of temporal adverbial clauses. In: English Language and Linguistics $13: 385-408$.

Haegeman, Liliane 2010a. Internal syntax of adverbial clauses. In: Lingua 120 :628-48.

Haegeman, Liliane 2010b. The movement derivation of conditional clauses. In: Linguistic Inquiry $41: 595-621$.

Haegeman, Liliane-Barbara Ürögdi 2010. Referential CPs and DPs: An operator movement account. In: Theoretical Linguistics 36:111-52.

Harada, Shin-ichi 1971. Ga-No conversion and idiolectal variations in Japanese. In: Gengo Kenkyu [Language Research] 60:25-38.

Harada, Shin-ichi 1976. Ga-No conversion revisited. In: Gengo Kenkyu [Language Research] $70: 23-38$.

Heycock, Caroline 1994. Focus projection in Japanese. In: Mercé Gonzàlez (ed.): Proceedings of NELS 24, 159-87. GLSA Publications, Amherst MA.

Heycock, Caroline 2008. Japanese -wa, -ga, and information structure. In: Shigeru Miyagawa - Mamoru Saito (eds): Handbook of Japanese linguistics, 54-83. Oxford University Press, Oxford.

Hiraiwa, Ken 2001. Nominative-genitive conversion revisited. In: Noriko Akatsuka (ed.): Japanese/Korean linguistics 10, 546-59. CSLI/The University of Chicago Press, Chicago.

Hiraiwa, Ken 2010a. Complement types and the CP/DP parallelism: A case of Japanese. In: Theoretical Linguistics $36: 189-98$.

Hiraiwa, Ken 2010b. Scrambling to the edge. In: Syntax $13: 133-64$.

Hoji, Hajime 1985. Logical Form constraints and configurational structures in Japanese. Doctoral dissertation, University of Washington.

Acta Linguistica Hungarica 59, 2012 
Hooper, Joan - Sandra Thompson 1973. On the applicability of root transformations. In: Linguistic Inquiry 4:465-97.

Hornstein, Norbert 1999. Movement and control. In: Linguistic Inquiry 30:69-96.

Huddleston, Rodney 1994. The contrast between interrogatives and questions. In: Journal of Linguistics $30: 411-39$.

Johnson, Kyle 1988. Clausal gerunds, the ECP and government. In: Linguistic Inquiry $19: 583-609$.

Karttunen, Lauri 1971. Some observations on factivity. In: Papers in Linguistics 4 : 55-69.

Kiparsky, Paul-Carol Kiparsky 1970. Fact. In: Manfred Bierwisch-Karl Erich Heidolph (eds): Progress in linguistics. A collection of papers, 143-73. Mouton, The Hague.

Kratzer, Angelika 1989. Stage-level and individual-level predicates. In: Emmon BachAngelika Kratzer - Barbara Partee (eds): Papers on quantification. University of Massachusetts, Amherst.

Kuno, Susumu 1973. The structure of the Japanese language. MIT Press, Cambridge MA.

Kuroda, Shige-yuki 1965. Generative grammatical studies in the Japanese language. Doctoral dissertation, MIT.

Kuroda, Shige-yuki 1988. Whether we agree or not: A comparative syntax of English and Japanese. In: Linguisticae Investigationes 12:1-47.

Kuroda, Shige-yuki 2005. Focusing on the matter of topic: A study of wa and $g a$ in Japanese. In: Journal of East Asian Linguistics 14:1-58.

Larson, Richard 1987. "Missing prepositions" and the analysis of English free relative clauses. In: Linguistic Inquiry $18: 239-66$.

Larson, Richard 1990. Extraction and multiple selection in PP. In: The Linguistic Review $7: 169-82$.

Maki, Hideki-Lizanne Kaiser-Masao Ochi 1999. Embedded topicalization in English and Japanese. In: Lingua 109:1-14.

Miyagawa, Shigeru 1993. LF Case-checking and minimal link condition. In: MIT Working Papers in Linguistics $19: 213-54$.

Miyagawa, Shigeru 2010. Why agree? Why move? Unifying agreement-based and discourse-configurational languages. MIT Press, Cambridge MA.

Miyagawa, Shigeru 2011. Agreements that occur mainly in the main clause. Ms. MIT (http://ling.auf.net/lingBuzz/001244).

Murasugi, Keiko 1991. Noun phrases in Japanese and English: A study in syntax, learnability and acquisition. Doctoral dissertation, University of Connecticut.

Nemoto, Naoko 1993. Chains and case positions: A study from scrambling in Japanese. Doctoral dissertation, University of Connecticut.

Oshima, David Y. 2007. On factive islands: Pragmatic anomaly vs. pragmatic infelicity. In: Takashi Washio-Ken Satoh-Hideaki Terada-Akihiro Inokuchi (eds): New frontiers in artificial intelligence: Joint JSAI 2006 workshop post-proceedings, 147-61. Springer, Dordrecht. 
Radford, Andrew 2009. Analysing English sentences: A minimalist approach. Cambridge University Press, Cambridge.

Radford, Andrew 2011. The complementiser system in spoken English: Evidence from broadcast media. Ms. University of Essex.

Rizzi, Luigi 1990. Relativised minimality. Cambridge MA, MIT Press.

Rizzi, Luigi 1997. The fine structure of the left periphery. In: Liliane Haegeman (ed.): Elements of grammar, 281-337. Kluwer, Dordrecht.

Rizzi, Luigi 2004. Locality and left periphery. In: Belletti (2004, 223-51).

Roussou, Anna 2000. On the left periphery: Modal particles and complementizers. In: Journal of Greek Linguistics $1: 65-94$.

Saito, Mamoru 1985. Some asymmetries in Japanese and their theoretical implications. Doctoral dissertation, MIT.

Saito, Mamoru 1992. Long distance scrambling in Japanese. In: Journal of East Asian Linguistics 1:69-118.

Starke, Michal 2001. Move dissolves into Merge: A theory of locality. Doctoral dissertation, University of Geneva.

Szabolcsi, Anna-Frans Zwarts 1993. Weak islands and algebraic semantics for scope taking. In: Natural Language Semantics 1:235-84.

Tada, Hiroaki 1993. A/A-bar partition in derivation. Doctoral dissertation, MIT.

Takano, Yuji 2010. Scrambling and control. In: Linguistic Inquiry 41:83-110.

Uchibori, Asako 2000. The syntax of subjunctive complements: Evidence from Japanese. Doctoral dissertation, University of Connecticut.

Ura, Hiroyuki 1993. L-relatedness and its parametric variation. In: MIT Working Papers in Linguistics 19:377-99.

Uriagereka, Juan 1999. Multiple spell-out. In: Samuel Epstein-Norbert Hornstein (eds): Working minimalism, 251-282. MIT Press, Cambridge MA.

Watanabe, Akira 1994. A cross-linguistic perspective on Japanese nominative-genitive conversion and its implications for Japanese syntax. In: Masaru Nakamura (ed.): Current topics in English and Japanese, 341-69. Hitsuji Shobo, Tokyo.

Watanabe, Akira 1996. Nominative-genitive conversion and agreement in Japanese: A cross-linguistic perspective. In: Journal of East Asian Linguistics 5 :373-410.

Yatsushiro, Kazuko 2003. VP internal scrambling. In: Journal of East Asian Linguistics $12: 141-70$. 